Anna Kociołek-Pęksa

\title{
PROBLEMATYKA AKSJOLOGICZNA JAKO UWARUNKOWANIE PROCESÓW PRAWODAWSTWA GOSPODARCZEGO ORAZ JEGO LIMITACJI. ZAGADNIENIA FILOZOFICZNOPRAWNE
}

\section{Wprowadzenie}

Przyczynkiem do podjęcia problematyki determinantów granic prawnej regulacji w sferze gospodarki jest uczucie głębokiego niepokoju, jakie wzbudza we mnie nadaktywność współczesnego prawodawcy oraz coraz bardziej dynamiczne i ekspansywne wkraczanie z regulacją prawną w całokształt stosunków społeczno-gospodarczych. Poszukiwania granic prawa doprowadziły mnie do podstawowego poziomu, $\mathrm{z}$ jakiego analizujemy prawo, a więc do poziomu podstaw prawa, czyli wartości, z których ono wyrasta, czy - co będzie celem tej pracy - wskazanie, z jakich wartości wyrastać powinno i zarazem je realizować. Wymaga to racjonalnego dyskursu o aksjologicznych podstawach prawa (mającego za przedmiot stosunki gospodarcze). Dyskurs ten pozwala na wyjaśnienie aksjologicznej genezy normatywności prawa, wskazując na ideę prawa złożoną z trzech wartości (celowość - sprawiedliwość - bezpieczeństwo prawne), jako ten element, który przesądza o ostatecznej ilości, zawartości i jakości prawa.

Współczesna gospodarka, której kształt nigdy nie jest stały ani ostateczny, jej dynamika, wieloaspektowość i innowacyjność powodują, że gospodarka ulega błyskawicznej ewolucji, wymykającej się z dróg ustalanych przez najsprawniejszego nawet ustawodawcę. Ten stan rzeczy powoduje, że regulacja prawna gospodarki znajduje się w stanie nieustannej nieodpowiedniości i nieprzystawalności wobec materii, którą reguluje. Ilość oraz szczegółowość regulacji gospodarczych powoduje, że w bardzo krótkim czasie od utworzenia stają się one nieaktualne $\mathrm{w}$ aspekcie wiedzy, którą wykorzystał prawodawca przy ich tworzeniu; stają się więc one po prostu zbędne, a w niektórych okolicznościach ich dalsze funkcjonowanie w systemie prawa jest dysfunkcjonalne. 
Powyższe fakty wpływają na stan i treść współczesnych dyskusji nad prawem oraz zasadnością i zakresem ingerowania przy jego użyciu w system gospodarczy. Głównym wątkiem tej dyskusji jest wątek określany mianem „No right answer?” oraz wykształcone w jego ramach dwa podejścia filozoficzno-prawne do koncepcji prawa. Stanowisko pierwsze zakłada świadome i zupełne odejście od normatywności prawa, a także konieczności jego aksjologicznej legitymizacji. Stanowisko drugie, czyniąc założenie o omnipotencji prawa, absolutyzuje je i poszukuje w nim jednoznacznych odpowiedzi na wszelkie problemy społeczne, w tym także gospodarcze. Te dwa stanowiska rzutują na kształtowanie się nowych - nierzadko skrajnych stanowisk badawczych. Możemy zauważyć ich ogromną rozbieżność, od skrajnych stanowisk odrzucających całkowicie przydatność prawa jako regulatora rzeczywistości społecznej, poprzez stanowiska zakładające możliwość sformułowania całkowicie nowego, a zarazem odmiennego od zastanego modelu prawa, aż po stanowiska starające się sformułować taką koncepcję prawa, na której gruncie prawo byłoby nie tylko uniwersalnym, ale i ostatecznym (absolutnym) regulatorem rzeczywistości oraz źródłem rozwiązywania wszelkich społecznych problemów.

Przyjmuję to ze wspomnianych stanowisk, które zakłada możliwość stworzenia nowego modelu prawa. Podjęte rozważania prowadzone więc będą na płaszczyźnie postulatywnej. Chodzi zatem o wskazanie owych elementów, które powinny stanowić fundament tworzenia prawa oraz równocześnie być finistycznym wyznacznikiem prawnej regulacji gospodarki, czyli stanowić skuteczną zaporę dla ewentualnej społecznie niepożądanej i/lub nieakceptowanej ingerencji prawnej

Podjęta problematyka domaga się potraktowania w odmienny od dotychczasowych sposobów, zwłaszcza w kontekście współcześnie występującego zjawiska, które można określić mianem „antropologicznego kryzysu prawa”. Jest on następstwem m.in. braku nawyku przestrzegania prawa oraz braku motywacji do jego przestrzegania przez jego adresatów. Wynika to z braku możliwości określenia aksjologicznych podstaw prawa, a przy możliwości ich określenia, z jej nieprzystawalności do przekonań aksjologicznych jednostek. Przy próbie rekonstrukcji takich podstaw okazuje się, że wartości, które prawodawca czyni przedmiotem ochrony prawnej, nie są tymi wartościami, których ochrony domagają się adresaci prawa. Pojawia się także problem rozbieżności w deklarowanych przez prawodawcę wartościach, które chciałby ochraniać, a tymi, które faktycznie chroni². Dochodzi do tego problem braku

1 „No Right Answer?” - określenie to pochodzi z artykułu R. Dworkina, No Right Answer?, (w:) Law, Morality and Society - Essays in Honour of H.L.A. Hart, P.M.S. Hacker, J. Raz, Oxford University Press, Oxford 1977.

2 Por. Z. Ziembiński, Kilka tez do dyskusji o moralności i prawie, „Państwo i Prawo” 1956, z. 11, (w:) Elementy socjologii prawa. Wybór tekstów, red. A. Kojder, E. Łojko, W. Staśkiewicz, A. Turska, 
adekwatności między regulacją prawną a rzeczywistością, do której się ona odnosi, oraz brak odpowiedniej, specjalistycznej wiedzy prawodawcy na temat materii, którą reguluje. Istniejąca fikcja prawa w postaci „racjonalności ustawodawcy”3 oraz „racjonalnej procedury" tworzenia prawa ${ }^{4}$ wcale sprawy nie ułatwia, a jedynie wprowadza dodatkowe komplikacje związane z rozumieniem i interpretacją tych wyrażeń, których dokonać można jedynie intuicyjnie.

Drugim problemem współczesnego prawa - ściśle wiążącym się z pierwszym - jest problem nadmiaru i inflacji prawa. Powstawanie coraz większej ilości regulacji prawnych cechujących się coraz większą szczegółowością, a wręcz kazuistyką powoduje, że adresaci prawa nie mają możliwości zapoznania się ze wszystkimi kierowanymi do nich normami prawa. Samo zaś intuicyjne postępowanie adresata mające na celu nienaruszenie dyspozycji adresowanych do niego norm prawa z reguły skazane jest na porażkę, ponieważ wartości i normy zinternalizowane przez adresata prawa, a wywodzące się z innych niż prawo systemów normatywnych, jeżeli stają się tymi wartościami, które prawodawca czyni przedmiotem ochrony, to bardzo często przypisuje im odmienne znaczenie od ustalonego i utrwalonego na gruncie norm pozaprawnych. Intuicyjne postępowanie adresata byłoby właściwe, gdyby - jak to podkreślał L. Petrażycki - prawodawca posługiwał się „normowaniem intuicyjno-prawnym”. Za trafny należy uznać pogląd L. Petrażyckiego głoszący, że istnieją w sferze normowania prawnego takie kwestie, „które ze względu na swą naturę wykluczają możliwość unormowania pozytywnego właściwego, odpowiadającego istocie spraw; aby osiągnąć przy rozstrzyganiu tych kwestii wyniki właściwe, należy stosować normowanie intuicyjno-prawne”. Zresztą

Wydawnictwo UW, Warszawa 1989, s. 128. Autor następująco ocenia postawę i motywy działania prawodawcy: „Jeśli nawet ustawodawca jest cynikiem, przy współczesnym rozwoju społeczeństwa względy taktyczne nakazują mu udawać, że motywem jego działania jest tak czy inaczej rozumiana troska o dobro innych".

${ }^{3}$ P. Dutkiewicz, Problem aksjologicznych podstaw prawa we wspótczesnej polskiej filozofii i teorii prawa, „Rozprawy Habilitacyjne” nr 317, Wydawnictwo UJ, Kraków 1996, s. 74. „Założenie, że działający prawodawca spełniający określone warunki jest doskonały, nie wynika z analizy praktyki prawotwórczej, lecz stanowi wyraz przyjętej a priori zasady racjonalności, a więc zasady idealizacyjnej, która może być stosowana i konkretyzowana jedynie intuicyjnie". Por także L. Nowak, Interpretacja prawnicza. Studium $z$ metodologii prawoznawstwa, PWN, Warszawa 1973.

${ }^{4} \mathrm{~W}$ polskiej nauce prawa model racjonalnego tworzenia prawa został sformułowany przez J. Wróblewskiego. Szerzej zob. J. Wróblewski, Zasady tworzenia prawa, PWN, Warszawa 1989, rozdz. 5 (s. 45-65). Por. także idem, Teoria racjonalnego tworzenia prawa, Zakład Narodowy im. Ossolińskich, Wrocław-Warszawa-Kraków-Gdańsk-Łódź 1985; S. Wronkowska, Problemy racjonalnego tworzenia prawa, Wydaw. Naukowe UAM, Poznań 1982; J. Wróblewski, Model racjonalnego tworzenia prawa problemy sporne, „Nowe Prawo” 1985; E. Kustra, Polityczne problemy tworzenia prawa, Wydawnictwo im. M. Kopernika, Toruń 1994.

${ }_{5}^{5}$ L. Petrażycki, Teoria prawa i państwa w związku z teorią moralności, PWN, Warszawa 1959-1960, s. 256 i 266.

${ }^{6}$ Ibidem. 
sytuacja, w której nie istnieje odpowiednia dla rozstrzygnięcia danego stanu rzeczy norma prawna, nie powinna skutkować podjęciem działań prawodawczych w celu stworzenia brakującej normy prawnej, lecz odnalezieniem odpowiedniego rozwiązania wśród norm pozaprawnych ${ }^{7}$.

Z całokształtu uregulowań prawno-gospodarczych wyłania się rażąca asymetria uprawnień i obowiązków oraz możliwości wzajemnego wiążącego kształtowania prawnej, a także faktycznej sytuacji twórców i adresatów prawa, która daje przewagę (dominującą pozycję) podmiotom prawodawczym.

Przyjęte podejście postulatywne sprowadza się więc do pewnych wskazań i zaleceń, które mają stanowić ograniczenie prawodawcy, a wynikają z przyjętej aksjologii. Przyjęte wartości stanowią pewien ideał (wzór), do którego należy nieustannie dążyć, gdyż w im większym stopniu uda się do niego przybliżyć, w tym mniejszym stopniu potrzebne będzie kreowanie i stosowanie środków kontroli i przymusu prawnego, a ostatecznie i samej regulacji prawnej. Poprawne i pełne zinternalizowanie owych wartości stanowiących trzon aksjologiczny danej zbiorowości skutkuje wytworzeniem się postaw proprawnych i brakiem konieczności stosowania przymusu prawnego. Przyjmuję także jedno z założeń charakteryzujących normatywne podejście do granic prawa, a polegające na uznaniu istnienia tzw. samoograniczeń prawa i ustawodawcy. Owe samoograniczenia są od prawodawcy niezależne, niezmienne i wiążące go. Przyjęto, że prawo nie odgrywa dominującej roli jako faktyczny regulator życia społecznego, a raczej stanowi rodzaj „ostatecznego zabezpieczenia” interesów członków danego stosunku społecznego w sytuacji kryzysowej

\section{Aksjologia w ujęciu filozoficznoprawnym}

Aksjologia we współcześnie nadawanym znaczeniu9 - czyli usystematyzowana teoria wartości - jako odrębna dyscyplina filozoficzna pojawiła się dopiero pod

7 Tak samo J. Zajadło, Dziedzictwo przeszłości - portret filozofa, prawnika, polityka i humanisty, Arche, Gdańsk 2007, s. 142: „Jeśli brakuje reguły prawnej mogącej być podstawą rozstrzygnięcia, nie oznacza to, że decyzja nie może być podjęta, ale jedynie to, że nie będzie podjęta na podstawie reguły prawnej”.

8 Por. K. Pałecki, Społeczne wyznaczniki skutecznego oddzialywania przy pomocy prawa na stosunki rodzinne, ,Rozprawy Habilitacyjne” nr 6, Wydawnictwo UJ, Kraków 1977, s. 52.

9 Aksjologia (ang. axiology) - „badanie wartości”, jak podaje Oksfordzki słownik filozoficzny, S. Blackburn, red. nauk. J. Woleński, KiW, Warszawa 1997, 2004, s. 15. Na temat aksjologii w kontekście prawa zob. P. Sut, Aksjologia a prawo, (w:) Leksykon wspótczesnej teorii i filozofii prawa. 100 podstawowych pojęć, red. J. Zajadło, C.H. Beck, Warszawa 2007, s. 1-8. 
koniec XIX wieku, czyniąc przedmiotem swych badań i analiz wartości ${ }^{10}$. H. Lotze wprowadził do swojego systemu filozoficznego pojęcie wartości, stając się twórcą dyscypliny o nazwie filozofia wartości ${ }^{11}$. Pod koniec tego samego wieku można było już zauważyć w literaturze różnorodność nadawanych temu pojęciu znaczeń, które nadal pozostawiały to pojęcie nieostrym i wieloznacznym. G. Kloska wskazał na dokonanie R. Lautmanna, który analizując niemiecką literaturę socjologiczną, natrafił na sto osiemdziesiąt osiem różnych definicji wartości ${ }^{12}$. Refleksje socjologa na temat wartości są uzasadnione tym, że - jak pisze J. Sztumski - „osobliwy świat wartości, w którym człowiek rodzi się, żyje i umiera, nie istnieje przecież poza światem ludzi”'13. Świat wartości nie jest jednak jednolity i uniwersalny, dlatego można dokonać wyróżnienia szeregu jego immanentnych właściwości. Pojęcie wartości nie posiada ustalonego znaczenia w naukach społecznych. Sam W. Tatarkiewicz twierdził, że zdefiniowanie wartości jest trudne, jeśli w ogóle możliwe. Bywa więc definiowane w bardzo różny sposób, jak też nie bywa definiowane wcale, będąc uznanym za pojęcie pierwotne. Najbardziej ogólne znaczenia przypisywane pojęciu wartości to: „1) to, co cenne; 2) to, co zgodne z naturą tego, kto wartościuje, 3) to, czego chcemy, a więc przedmiot naszego dążenia, pożądania, cel; 4) to, czego pożądamy pożądać; 5) to, co zaspokaja jakieś potrzeby, zainteresowania, 6) to, co dostarcza zadowolenia, przyjemności; 7) to, co powinno być; 8) to, co lepiej, żeby było, niż nie było; 9) to, co domaga się realizacji”"14.

Znaczenia te wypływają bowiem z trializmu aspektów charakteryzujących każdą wartość, które to aspekty zdaniem T. Parsonsa zawiera każda definicja wartości, a są nimi:

1) aspekt uczuciowy - afektywny („godne pożądania”),

2) aspekt poznawczy - wiedza („koncepcja”),

3) aspekt wolicjonalny („selekcja”) ${ }^{15}$.

${ }^{10}$ A. Kojder, Godność i siła prawa. Szkice socjologicznoprawne, Oficyna Naukowa, Warszawa 2001, s. 488. Filozofowie nie posługiwali się bowiem jednym ogólnym pojęciem wartości. Najczęściej problematyka aksjologiczna wyprowadzana była z pojęcia dobra.

${ }^{11}$ H. Schändelbach, Filozofia $w$ Niemczech 1831-1933, Wydawnictwo Naukowe PWN, Warszawa 1992, s. 256.

12 G. Kloska, Pojęcie, teorie i badania wartości w naukach społecznych, Warszawa 1982, s. 29-30, podaję za: A. Kojder, op.cit.

13 J. Sztumski, Społeczeństwo i wartości, „Prace Naukowe Uniwersytetu Śląskiego w Katowicach” nr 1292, Katowice 1992, s. 7.

${ }_{14}$ M. Kordela, Zarys typologii uzasadnień aksjologicznych w orzecznictwie Trybunału Konstytucyjnego, Oficyna Wydawnicza Branta, Bydgoszcz-Poznań 2001, s. 25; por. A.B. Stępień, Wstęp do filozofii, Towarzystwo Naukowe Katolickiego Uniwersytetu Lubelskiego, Lublin 1989, s. 95.

15 Por. J. Jakubowski, Racjonalność i normatywność działań (Alfred Schutz a Talcott Parsons), „Pisma Filozoficzne" t. LIII, Uniwersytet im. A. Mickiewicza w Poznaniu, Wydawnictwo Naukowe Instytutu Filozofii, Poznań 1998, s. 124. 
Przyjmując taką budowę definicji wartości oraz dokonując jej analizy, R. Spaeman dochodzi do wniosku, iż wartości nie stanowią następstwa ani też przyczyny naszych odczuć, stanowią natomiast przedmiot naszego odczuwania ${ }^{16}$. Dzięki nim jesteśmy zdolni do współpracy z innymi jednostkami w ramach określonych zbiorowości, ponieważ - zdaniem R. Spaemana - wartości służą urzeczywistnianiu indywidualnych, a także wspólnych celów tych jednostek, których dotyczy działanie innych jednostek ${ }^{17}$. Ten sposób rozumienia wartości umożliwia dokonanie typologii wartości, którym prawo ma służyć, na dwa podstawowe rodzaje: „z jednej strony wyróżnić należy wartość prawa jako środka osiągania czy zabezpieczania stanów rzeczy korzystnych dla poszczególnych jednostek lub wąskich kategorii społecznych, z drugiej strony - środka służącego osiąganiu dóbr cennych dla społeczeństwa jako całości”18.

Z. Ziembiński uważał, że takie dualistyczne rozróżnienie wartości powoduje konieczność zwrócenia szczególnej uwagi „na przypadki, w których interesy partykularne przeciwstawiają się interesom ogółu, czy też przypadki, w których interes ogółu w bardzo zawiły tylko sposób daje się sprowadzić do interesów indywidualnych, i to z poświęceniem którychś z konkurencyjnych interesów indywidualnych $\mathrm{w}$ imię innych"19. Pojęcie interesu ${ }^{20}$ jest $\mathrm{w}$ rozważaniach autora utożsamiane z pojęciem wartości. Autor akcentuje więc konfliktowy charakter wartości i uważa, że nie jest możliwe zachowanie między nimi stanu równowagi oraz równoczesna realizacja jednych i drugich. Pogląd o konieczności poświęcania jednych wartości na rzecz realizacji innych nie jest do końca poprawny. Skłaniam się raczej do przyjęcia koncepcji zakładającej dokonywanie wyboru między wartościami, co nie jest równoznaczne z poświęcaniem niektórych wartości.

Wybór zakłada bowiem, że w momencie jego dokonywania decydujemy się realizować określoną wartość, a realizację innej np. odkładamy w czasie lub też uznajemy, że nie chcemy jej już realizować, ponieważ tak naprawdę nie stanowi dla nas wartości, albo zakładamy, że mimo dokonanego wyboru uda nam się doprowadzić jednak do jej realizacji w jakiś sposób tzw. przy okazji. Jak pisał R. Ingarden, „do istoty wartości należy, że coś w nich skłania nas do wyboru, którą z nich »należy« realizować,

\footnotetext{
${ }_{16}$ R. Spaeman, Granice, Oficyna Naukowa, Warszawa 2006, s. 207.

17 Por. ibidem, s. 204. Podając przykład wartości służących wspólnemu celowi, autor odwołuje się do Hansa Kunga, którego zdaniem wartości pokoju i przetrwania ludzkości są tymi wartościami - celami, wobec których wszelki ethos jest podporządkowany i pełni funkcję instrumentalną. (Autor odsyła do H. Kung, Projekt Weltethos, Piper, München 1990).

${ }^{18}$ Z. Ziembiński, Wstęp do aksjologii dla prawników, Wydawnictwo Prawnicze, Warszawa 1990, s. 98.

${ }^{19}$ Ibidem, s. 98.

${ }^{20}$ Autor, niestety, nie uwzględnia w swoich rozważaniach wprowadzonego przez Vilfreda Pareto pojęcia interesu subiektywnego i obiektywnego. Zob. V. Pareto, Uczucia i działania. Fragmenty socjologiczne, Wydawnictwo Naukowe PWN, Warszawa 1994, s. 215 i n.
} 
gdy nie jest możliwa realizacja na przykład dwu różnych wartości, których warunki zaistnienia się wykluczają"21.

Wydaje się więc, że proces decyzyjny podmiotu warunkowany jest istotą wartości, z której to istoty wynika możliwość dokonania wyboru. Podobnie jak R. Ingarden problematykę wyboru między wartościami widzi J. Sztumski. Uważa on, że proces decyzyjny wynika z subiektywnego charakteru wartości, bo, jak stwierdza, „to, który z danych przedmiotów lub która z danych cech czy idei zostanie uznana za wartość, zależy od decyzji podmiotu wynikającej z jego aktywnej postawy wobec rzeczywistości, w jakiej istnieje"22. Połączenie ze sobą subiektywnej istoty wartości oraz przyjmowanej przez jednostkę postawy przesądza więc o tym, co jednostka uzna za wartości oraz które $z$ uznanych wartości będzie realizować. A zatem między wartościami nie dochodzi do sprzeczności, która skutkowałaby koniecznością poświęcania jednych w imię realizacji innych. Realizować je można łącznie, pojawia się jednak pytanie o efektywność i skuteczność stopnia realizacji każdej z nich. Możemy tutaj mówić raczej o ewentualnej niezgodności prakseologicznej, o której pisał Z. Ziembiński, charakteryzując relacje zachodzące między normami prawnymi. Zdaniem Z. Ziembińskiego „o niezgodności prakseologicznej norm mówi się w tych przypadkach, gdy wprawdzie możliwe jest zrealizowanie wszystkich wchodzących w rachubę norm przez ich adresata, jednak zrealizowanie jednej z nich niweczy całkowicie czy też w istotnym (ale jak istotnym?) stopniu rezultaty zrealizowania pozostałych norm. Innymi słowy, chodzi o te przypadki, gdy rozważane normy są wprawdzie realizowane razem, ale jedne marnotrawią wysiłek użyty na zrealizowanie innych"23. Należy uznać, że niezgodność taka może także wystąpić właśnie między wartościami, które stanowią przecież przedmiot ochrony norm prawnych i ratio ich utworzenia.

J. Sztumski wskazuje ponadto, że w systemie społecznym wartości pełnią funkcje o charakterze: integracyjnym, inspiracyjnym i zabezpieczającym ${ }^{24}$, umożliwiając uzgadnianie konkurujących wartości - celów między jednostkami, stwarzając jednocześnie podstawy do współdziałania w ich osiąganiu i budowaniu trwałych

\footnotetext{
${ }^{21}$ R. Ingarden, Przeżycie, dzieło, wartość, Wydawnictwo Literackie, Kraków 1996, s. 97.

22 J. Sztumski, op.cit., s. 10.

${ }^{23}$ S. Wronkowska, Z teorii i filozofii prawa Zygmunta Ziembińskiego, Wolters Kluwer Bussines, Warszawa 2007, s. 265.

24 „[...] integracyjnej funkcji wartości upatruje w tym, że poszczególne wartości łączą tych, którzy je wyznają i kieruja się nimi w swoim działaniu. Wartości stają się zatem podstawa do tworzenia rozmaitych instytucji i organizacji w obrębie systemu. [...] Ludzie zintegrowani określonymi wartościami podejmują więc rozmaite wspólne działania dla urzeczywistnienia wspólnych wartości. [...] Istniejący w danym systemie społecznym układ wartości pełni również funkcje sankcjonującą różne instytucje, cele, dążenia itp. jego wytwory społeczne, a tym samym umożliwiającą nie tylko jego egzystencjalne funkcjonowanie. $\mathrm{Z}$ tym faktem wiąże się więc jego funkcje zabezpieczającą system społeczny przed ewentualną groźbą rozpadu”. J. Sztumski, op.cit., s. 29-30.
} 
zespołów społecznie uznawanych wartości - celów oraz sposobów ich osiągania. Te właśnie argumenty przesądziły o przyjęciu przeze mnie koncepcji liberalizmu gospodarczego i liberalizmu światopoglądowego, ponieważ liberalizm pozwala na najbardziej optymalne rozstrzygnięcie kwestii zgodności lub rozbieżności interesów indywidualnych z interesami społecznymi poprzez odwołanie się do utylitarystycznego założenia, że „kto nie dba o przyjemności, jest niemoralny i niebezpieczny, jako że swym postępowaniem łatwo sprzeniewierzyć się może zasadzie użyteczności, która [...] jest zasadą moralną". Ponadto „branie pod uwagę w swoim postępowaniu także interesu innych jest korzystne dla nas samych"25.

Zatem społeczna współpraca i kooperacja podmiotów gospodarujących musi opierać się na określonych wartościach, których trialistyczna budowa - zgodnie z modelem T. Parsonsa - powoduje, że w ich charakterze możemy dopatrzyć się także trzech właściwości, ponieważ każda wartość jest równocześnie zjawiskiem kulturowym, zjawiskiem psychologicznym oraz zjawiskiem socjologicznym ${ }^{26}$.

Jako poprawne i użyteczne z punktu widzenia prawodawstwa gospodarczego należy przyjąć takie znaczenie terminu wartość, jakie nadał mu we współczesnej socjologii prawa K. Pałecki. „Wartością może stać się dowolny obiekt, rzecz, rodzaj aktywności, konstrukcja myślowa, stany świadomości. Wartość ma bowiem charakter relacyjny, to znaczy „istnieje” tylko wtedy, gdy określony podmiot odczuwa szczególny rodzaj apulsywnego stosunku emocjonalnego do dowolnego obiektu; pożądanie, chcenie, pragnienie, aby określony stan zaistniał lub/i był ochroniony lub/i był pomnożony"27. Przy takim rozumieniu wartości konsekwentnie należy przyjąć sformułowaną przez autora definicję antywartości ${ }^{28}$.

Zarówno wartości, jak i antywartości są hierarchicznie uporządkowane w świadomości każdej jednostki w indywidualny, jej tylko właściwy sposób. Z. Ziembiński uważał, że już samo pojęcie wartości pozwala stworzyć wielostopniową gradacyjną skalę wartości ${ }^{29}$. Takie hierarchiczne porządki wartości - zwane skalami preferencyjnymi $^{30}$ - charakteryzują się bardzo dużym zróżnicowaniem, a nawet przeciwnościami w odmiennym sposobie preferencji (rozmieszczenia/umiejscowienia) określonych wartości i antywartości u poszczególnych jednostek, dlatego nie zawsze

\footnotetext{
25 J. Hartman, Wstęp do filozofii, Wydawnictwo Naukowe PWN, Warszawa 2005, s. 145-147.

26 Por. M. Misztal, Problematyka wartości w socjologii, PWN, Warszawa 1980, s. 14-19.

${ }^{27}$ K. Pałecki, Prawoznawstwo. Zarys wykładu. Prawo w porządku społecznym, Difin, Warszawa 2003, s. 78.

28 Autor przyjmuje, że rozumienie antywartości jako „obiektów (stanów rzeczy) w różnym stopniu przez podmioty niechcianych (niepożądanych). Antywartości są następstwem przeżywania emocji repulsywnych (odrzucających, odpychających) związanych z odpowiednio negatywnymi ocenami”. Ibidem, s. 80

${ }^{29}$ Z. Ziembiński, Wstęp do aksjologii..., op.cit., s. 59.

${ }^{30}$ K. Pałecki, Prawoznawstwo..., op.cit., s. 81.
} 
istnieje możliwość uzgodnienia czy nawet pogodzenia ze sobą różnych skal preferencyjnych. Problem ten występuje także pomiędzy skalami preferencyjnymi adresatów prawa oraz skalą preferencyjną prawodawcy. Istnieją pewne wartości, które są bardziej cenione przez jedną ze stron, a zatem zajmujące wyższe miejsce w jej hierarchii wartości, natomiast te same wartości mogą być dla drugiej strony mniej cenne, a zatem znajdujące się niżej w jej hierarchii wartości. W skrajnych wypadkach to, co jedna ze stron uzna za wartość, dla drugiej może być stanem neutralnym, a nawet antywartością. Hierarchicznie uporządkowane zbiory wartości tworzą się w następstwie dokonywanych przez nas wyborów realizacji określonych norm, a wynikają z naszych indywidualnych preferencji. Realizacja jakiegokolwiek stosunku społecznego stanowi akt wyboru, a ratio tego wyboru znajduje się na skali preferencyjnej jednostki dokonującej wyboru.

Pojawia się tutaj problem możliwości wskazania trzonu aksjologicznego składającego się z wartości, które dla większości jednostek byłyby w takim samym stopniu cenne, a zatem znajdowałyby się na skalach preferencyjnych poszczególnych jednostek podobnie wysoko. K. Pałecki stwierdza, że istnieją takie wartości, które „zachowują relatywnie trwale wysokie miejsca w większości skal preferencyjnych u ludzi wychowanych w tej samej kulturze i w określonym przedziale czasu. W tym sensie można mówić o wartościach społecznych (czyli względnie trwałych i powszechnie podzielanych $w$ danym społeczeństwie), a także o podobnym ich uporządkowaniu, relatywnie trwałym i najczęstszym w danym społeczeństwie, czyli o społecznych skalach preferencyjnych"31.

Również dla T. Parsonsa najistotniejszymi wartościami były wartości społeczne, które rozumiał jako koncepcje wartego pożądania typu społeczeństwa ${ }^{32}$. W literaturze wskazuje się jako przykład takich wartości - traktowanych jako nadrzędne cele społeczne - dobro wspólne, sprawiedliwość społeczną, wolność jednostki, równość, rozwój społeczny, solidarność, uznając je tym samym za zbiór wartości stanowiących fundament aksjologiczny, czyli czynnik legitymizujący określoną koncepcję porządku społecznego, a przede wszystkim systemu gospodarczego ${ }^{33}$. Legitymizacja wartości stanowiła przy tym dla Parsonsa płaszczyznę utrwalania się wartości społecznych, rozumiał ją bowiem jako „ocenę działania z punktu widzenia podzielanych lub wspólnych wartości, w kontekście włączania działania w system społeczny”34.

\footnotetext{
${ }^{31}$ Ibidem, s. 82.

32 T. Parsons, Struktura społeczna a osobowość, PWE, Warszawa 1969, s. 249.

33 Elementy etyki gospodarki rynkowej, red. B. Pogonowska, PWE, Warszawa 2000, s. 82 (tekst B. Pogonowskiej).

34 T. Parsons, Structure and Process in modern Societies, The Free Press, New York 1965, s. 175. Płaszczyznę legitymizacji poprzedzają: płaszczyzna uzasadniania, na której dokonuje się ugruntowanie wartości
} 


\section{Aksjologiczny charakter uregulowań prawnych}

Prawo - w tym prawo gospodarcze - ma charakter aksjologiczny, ponieważ jest tworzone po to, aby służyć ochronie i realizacji określonych wartości. Należy zauważyć, iż zasady tworzenia prawa - technika prawodawcza - opierają się na założeniu aksjologicznej racjonalności działania prawotwórczego ${ }^{35}$. Zdaniem I.C. Kamińskiego tworzone prawo musi odzwierciedlać system społecznych wartości, a względy słuszności powinny decydować o tym, czy stworzone prawo można uznać za obowiązujące, czyli należycie ochraniające i umożliwiające realizację społecznych wartości ${ }^{36}$. Także R. Sarkowicz i J. Stelmach stwierdzają, że każdy konkretny materialno-pozytywny system prawa zawsze urzeczywistnia określony system wartości ${ }^{37}$. Pojawia się jednak pytanie, czy są to wartości społeczne. Tworzenie norm prawnych, których podstawą są wartości nieuspołecznione, może powodować, że powstałe normy nigdy się nie uspołecznią, a zatem nie będą dla swoich adresatów stanowić wzoru ich faktycznego postępowania. Przyjmuję tutaj pogląd A. Swidler, zgodnie z którym podzielane wartości nie muszą prowadzić do podobnych działań, ani nawet bezpośrednio wiązać się z działaniami ${ }^{38}$. Muszą jednak pozostawać względem siebie przynajmniej w stosunku niezależności, aby nie uniemożliwiły lub zakłócały wzajemnej realizacji. Pozostaną zatem jedynie „prawem oficjalnym”, natomiast jednostki kształtować będą swoje postępowanie zgodnie z normami „prawa żywego"39.

$\mathrm{Z}$ aksjologicznego charakteru wypływają inne właściwości, które prawo równocześnie posiada: ma ono także charakter normatywny, instrumentalny oraz społeczny. R. Pound przyjmuje, że „normatywność prawa wyraża się w tym, że jest ono systemem reguł formułujących sposoby zachowania się. Ma ono [prawo - przyp. mój,

poprzez odwołanie się do przekonań jednostek, oraz płaszczyzna motywacji, w której ramach jednostka ocenia, w jakim stopniu realizacja danej wartości zaspokoi jej potrzeby.

${ }^{35}$ Zob. J. Wróblewski, Zasady tworzenia prawa, op.cit., rozdz. V; por. także Z. Ziembiński, Wstęp do aksjologii..., op.cit., s. 162-170, 187-196.

36 I.C. Kamiński, Stuszność i prawo. Szkic prawnoporównawczy, Zakamycze, Kraków 2003, s. 16-17.

37 Por. R. Sarkowicz, J. Stelmach, Teoria prawa, Wydawnictwo UJ, Kraków 1997, s. 184.

38 A. Swidler, Culture in Action: Symbols and Strategies, „American Sociological Reviev” 1986, Nr 51, s. 274. Por. A. Giza-Poleszczuk, M. Marody, A. Rychard, Strategie i system. Polacy w obliczu zmiany systemowej, Wydawnictwo IFIS PAN, Warszawa 2000; M. Marody, Pojęcie wartości w wyjaśnianiu zachowań społecznych, (w:) Podstawy życia społecznego w Polsce, red. M. Marody, E. Gucwa-Leśny, Instytut Studiów Społecznych UW, Warszawa 1996.

${ }^{39}$ E. Ehrlich jest twórcą podziału prawa na „lebendes Reht”, czyli prawo żywe i prawo oficjalne (pozytywne). Uważał, że prawo żywe jest kategorią szerszą, której jedynie fragmentem jest prawo oficjalne. Prawu żywemu przypisywał rolę motywowania i kształtowania ludzkich działań. Prawo żywe to reguły, które funkcjonują w świadomości społecznej jako prawo, mimo że nie są prawem pozytywnym. Kształtuje się ono spontanicznie. Szerzej zob. J. Stelmach, R. Sarkowicz, Filozofia prawa XIX i XX wieku, Wydawnictwo UJ, Kraków, s. 89-92. 
A.K.P.] charakter instrumentalny jako środek celowego wpływania na zachowanie jego adresatów oraz, poprzez to, na utrzymanie lub zmianę określonych stosunków społecznych" ${ }^{30}$. Przyjmując normatywność wartości oraz prawa, przyjąć możemy istnienie społecznych skal preferencyjnych w odniesieniu do wartości realizowanych w gospodarce przez poszczególne podmioty. Można także wskazać - jak czynił to G. Radbruch - że wartościami, które mogą zostać uznane za społeczne i wysoko cenione przez jednostki gospodarujące, a także prawodawcę, będą wartości celowości, sprawiedliwości i bezpieczeństwa prawnego ${ }^{41}$ połączone w trójelementowej idei prawa.

G. Radbruch uważał, że „trzy podstawowe wartości, między którymi każdy konkretny system prawa utrzymuje względną równowagę, to bezpieczeństwo prawne, sprawiedliwość i celowość. Pominięcie którejś z tych wartości w określonym stopniu (niemożliwym do jednoznacznego zdefiniowania) powoduje, że przestajemy mieć do czynienia z prawem"42. Wspominane wartości są znane od wieków, a postulaty konieczności ich ochrony pojawiały się zarówno ze strony prawodawców, jak i adresatów prawa na gruncie całokształtu stosunków społecznych. Przyjmuję zatem, że wartości składające się na Radbruchowską triadę są trwałe, gdyż wykazują nieprzemijającą żywotność i budzą powszechną akceptację ${ }^{43}$. Wartości te są więc dobrze uspołecznione - problem tkwi jednak w przypisaniu im przez prawodawcę i adresatów prawa wspólnej, uzgodnionej i wzajemnie akceptowalnej treści. Dążenie do uzgodnienia wspólnego zbioru najważniejszych (podstawowych, naczelnych) wartości oraz przypisania im uzgodnionego znaczenia wynika z samej natury społeczeństwa, ponieważ dzięki temu dążeniu możliwe staje się zaprowadzanie i utrzymanie przynajmniej minimalnego stopnia porządku społecznego ${ }^{44}$. W tym miejscu należy przyjąć za K. Pałeckim, iż „te najbardziej cenione (najwyżej umieszczane w skalach preferencyjnych), relatywnie trwałe i powszechne wartości, o ile staną się przedmiotem odpowiedniej regulacji normatywnej, określającej sposób ich osiągania

40 Zob. P. Dutkiewicz, op.cit., s. 43.

${ }^{41}$ Podobnie P. Sut, który stwierdza: „można zapewne przyjąć, że w ramach kultury danego społeczeństwa możliwe jest wyróżnienie kategorii podstawowych wartości wspólnych dla tego społeczeństwa, takich jak np. bezpieczeństwo prawne, słuszność, sprawiedliwość [...]”. Zob. P. Sut, op.cit., s. 6.

${ }^{42}$ G. Radbruch, Gesetzliches Unrecht und Übergesetzliches Recht, (w:) G. Radbruch, Der Mensch in Recht, Göttingen 1961, s. 111-124; podaję za: J. Guść, Aspekty rozważań o granicach prawa, „Gdańskie Studia Prawnicze" t. VII, Gdańsk 2000.

${ }^{43}$ Por. J. Sztumski, op.cit., s. 18-21.

44 Por. T. Parsons, R.F. Bales, Family, Socializationand Interaction Process, Glencoe 1955, s. 167. T. Parsons uważa, iż nie istnieje porządek społeczny bez wspólnych wartości. Odmiennie uważa A. Schutz, który stwierdza, że działania jednostek nie są świadomie zorientowane na wartości. Por. A. Schutz, Choosing among Project soft Action, (w:) A. Schutz, Collected Papers, Vol. 1: The Problem of Social Reality, Springer, The Hague 1962, s. 94. 
(chronienia, pomnażania), a także dystrybucji lub/i partycypacji w nich określonych podmiotów, przesądzają o charakterze porządku społecznego" ${ }^{45}$. Zgadzam się także z twierdzeniem autora, że ,jeżeli podstawę aksjologiczną danych norm stanowią wartości, których w żaden sposób nie można uzgodnić ze skalami preferencyjnymi adresatów norm, lub co gorzej, są dla nich antywartościami, to należy spodziewać się odrzucenia tych norm"46.

Mówiąc więc o konieczności stworzenia podstawy aksjologicznej, nie można pominąć stanowiska Z. Baumana, który wprost stwierdza, że mają to być wartości „»uzgodnione«, "wspólne«, "nobilitowane« - nobilitowane przez akt wspólnego odczuwania i przez wyartykułowaną lub milczącą zgodę na poszanowanie tego, co wspólne" ${ }^{\prime 47}$. W literaturze, przede wszystkim z zakresu nauk ekonomicznych (głównie przedstawiciele szkoły klasycznej w ekonomii oraz kontynuatorzy ich myśli), odrzuca się konfliktową wizję społeczeństwa, przyjmując wizję kooperacyjną, która zakłada, że „społeczność, która mimo różnic interesów i przekonań troszczy się o to, by zachować porządek opierający się na najważniejszych wartościach, będzie w stanie uporać się z niedogodnościami pluralizmu, oraz że pluralistyczna społeczność jest skazana na szukanie konsensusu co do reguł współżycia i rozwiązywania konfliktów oraz wartości koniecznych dla uzasadnienia reguł i instytucji społecznych"48.

Przedstawione stanowiska potwierdzają więc poprawność przyjętego założenia, że istotą oraz podstawą wszelkich regulacji prawnych powinny być społecznie podzielane wartości, które racjonalizują czy też nadają sens tworzonym normom prawnym. Trafnie ujmuje to T. Biernat, stwierdzając, iż „przyjęcie stanowiska, że u podstawy norm stanowiących system lub podsystem normatywny leżą wartości, rozbija wprawdzie jednolity charakter norm, decydujących o postępowaniu jednostek w zbiorowości, ale pozwala na ich »zakotwiczenie «"49. Podobnie uważa G. Skąpska, która stwierdza, że „prawo jest częścią systemu społecznego m.in. w tym sensie, iż jest ono instytucją zakorzenioną w społecznych systemach wartości”"50.

45 K. Pałecki, Prawoznawstwo..., op.cit., s. 82; por. także A.R. Radcliffe-Brown, Structure and Function in Primitive Society, Free Press, New York 1965, s. 140 i n., podaję za: K. Pałecki, ibidem, s. 82.

46 K. Pałecki, ibidem, s. 158.

47 Z. Baumann, Zindywidualizowane społeczeństwo, Gdańskie Wydawnictwo Psychologiczne, Gdańsk 2008, s. 10 .

48 B. Sutor, Etyka polityczna. Ujęcie całościowe na gruncie chrześcijańskiej nauki społecznej, Warszawa 1994, podaję za: P. Sut, Aksjologia a prawo, op.cit., s. 7.

49 T. Biernat, Legitymizacja władzy politycznej. Elementy teorii, Wydawnictwo A. Marszałek, Toruń 1999, s. 128. Autor stwierdza także, że „aksjologiczne ukorzenienie systemów (subsytemów) [...] wydaje się być szeroko podzielane”, dowołując się m.in. do koncepcji systemu społecznego K. Pałeckiego. Por. K. Pałecki, Prawo. Polityka. Władza, COMSNP, Warszawa 1988, s. 17.

50 G. Skąpska, Prawo a dynamika społecznych przemian, „Rozprawy Habilitacyjne” nr 227, Wydawnictwo UJ, Kraków 1991, s. 18-19. 


\section{Próba deskrypcji wartości i odnalezienia ich istoty}

Pytanie „czym są wartości” bądź też „w jaki sposób istnieją” jest tak naprawdę pytaniem o ontologię aksjologii, a udzielenie odpowiedzi na to pytanie - jak zauważa G. Kloska - konstytuuje aż pięć zasadniczych stanowisk aksjologicznych ${ }^{51}$.

„1. Stanowisko kulturowe (relatywistyczne) - uzasadniane m.in. przez T. Parsonsa utrzymuje, że wartości są zjawiskami kulturowymi, które można zdefiniować jako ustalone społeczną praktyką i przekazywane z pokolenia na pokolenie standardy aprobowanego postępowania.

2. Stanowisko naturalistyczne (obiektywistyczne) głosi, że wartością jest wszystko, co pozwala człowiekowi optymalnie funkcjonować, realizować założone cele, zaspokajać potrzeby.

3. Stanowisko emotywistyczne (inaczej zwane subiektywistycznym) wyraża pogląd, że wartości są wyrazem przeżyć uczuciowych, afektywnym aspektem świadomości, swoistą reakcją emocjonalną.

4. Stanowisko heteronomiczne (reprezentuje je m.in. R. Ingarden) zakłada, że wartości istnieją tylko ze względu na ich nosicieli.

5. Stanowisko autonomiczne (inaczej absolutystyczne) utrzymuje, że wartościami są idee, przedmioty idealne, dobra absolutne" ${ }^{\text {"5 }}$.

Różni autorzy odwołują się do poszczególnych z wyżej wymienionych stanowisk, a nawet do kilku łącznie, należy jednak przyjąć, że „natura wartości” jest wieloaspektowa poprzez to, że łączy w sobie elementy poszczególnych stanowisk. Zdecydowanie odrzucam koncepcje zakładające obiektywny sposób istnienia wartości ${ }^{53}$. Przyjmuję, że wartości mają charakter heteronomiczno-emotywistyczny warunkowany kontekstem kulturowym ${ }^{54}$. Następstwem takich założeń jest więc relatywizm wartości, który polega na tym, że forma wartości, którą jest powinność, pozostaje niezmienna, natomiast treść wartości ulega zmianie, w zależności od zmiany miejsca, czasu, a przede wszystkim podmiotu przeżywającego relacje apulsji lub repulsji. Odwołuję się przy tym do relatywizmu w postaci, jaka była przyjmowana przez G. Radbrucha.

\footnotetext{
${ }^{51}$ Zob. G. Kloska, op.cit., s. 42-58.

52 Ibidem. Rozróżnieniem tym posługuje się także A. Kojder, op.cit., s. 489.

53 Obiektywny sposób istnienia wartości przyjmował np. K. Ajdukiewicz, a w przypadku wartości moralnych uważał ponadto, że istnieją w sposób bezwzględny. Zob. A. Jedynak, Ajdukiewicz, Wiedza Powszechna, Warszawa 2003, s. 120.

${ }_{54}$ Taki charakter wartości wynika bowiem wprost z przyjętej wcześniej definicji wartości K. Pałeckiego.
} 


\section{Relatywizm wartości}

Źródło relatywizmu Radbrucha stanowi - zdaniem M. Szyszkowskiej - uwzględnienie przez niego czynników społeczno-ekonomiczno-historycznych, które były pomijane przez I. Kanta ${ }^{55}$. J. Zajadło zauważa, że „Radbruch zajmuje stanowisko identyczne jak Max Weber i w konsekwencji podobnie jak u Webera relatywizm nie oznacza etycznego nihilizmu, wręcz przeciwnie, jak sam napisał, naturalną konsekwencją relatywizmu jest pozytywizm ${ }^{56}$, liberalizm, tolerancja, państwo prawa, podział władzy, demokracja [...]"57. Stanowisko M. Webera dotyczące wartości sprowadzało się do następujących zasadniczych tez:

„Pierwsza teza głosi irracjonalność wartości: nie tylko empiryczna nauka nie może uzasadniać wartości, w ogóle nie można uzasadnić ich racjonalnie, są przyjmowane na zasadzie decyzji. Druga teza głosi, iż istnieje wiele kolidujących ze sobą wartości i sfer wartości, czyli politeizm wartości. Weber w przeciwieństwie do innych filozofów wartości, np. Rickerta, nie wierzył w możliwość istnienia systemu wartości, a więc w ich możliwości uporządkowania i zharmonizowania w jednej całości. [...] Uważał, iż wartości z konieczności pozostają ze sobą w konflikcie"s8.

Nie zgadzam się jednak z twierdzeniem, że Radbruch przyjął za Weberem tezę o konfliktowym charakterze wartości ${ }^{59}$. Uważam, iż Radbruch przyjął założenie, że poszczególne wartości składające się na ideę prawa mają antynomiczny charakter, skutkujący tym, iż w pewnych warunkach niemożliwa jest pełna, równoczesna realizacja wszystkich trzech wartości, co powoduje, że którejś z nich musimy przyznać pierwszeństwo $\mathrm{w}$ realizacji. Jednak nie jest to równoznaczne $\mathrm{z}$ występowaniem konfliktu między tymi wartościami. Konflikt bowiem ma charakter destrukcyjny, natomiast relatywizm wartości w połączeniu $\mathrm{z}$ ich antynomicznością ma charakter konstruktywny.

Cenność relatywizmu G. Radbrucha polega na tym, że umożliwia on równoprawność różnorodnych światopoglądów. M. Szyszkowska opisuje to w następujący sposób: „Relatywizm głoszony przez G. Radbrucha prowadzi do swoistej aprobaty rzeczywistości społecznej. Wyraża się on w powstrzymywaniu się przed ustaleniem

${ }_{55}$ M. Szyszkowska, Zarys filozofii prawa, Temida 2, Białystok 2000, s. 215.

56 „Radbruch odchodzi od pozytywistycznego ujęcia prawa, od formalizmu prawa [...], dostrzegając społeczną realność prawa i jego wymiar aksjologiczny”. I. Gołowska, Antynaturalistyczna filozofia prawa Gustawa Radbrucha, (w:) Studia z filozofii prawa, red. J. Stelmach, Wydawnictwo UJ, Kraków 2001, s. 150.

57 J. Zajadło, Formuła Radbrucha. Filozofia prawa na granicy pozytywizmu prawniczego i prawa natury, Arche, Gdańsk 2001, s. 155.

58 Z. Krasnodębski, M. Weber, Wiedza Powszechna, Warszawa 1999, s. 40-41.

${ }_{59}$ Szerzej na temat konfliktowego charakteru wartości idei prawa u G. Radbrucha zob. J. Zajadło, Gesetz und Recht, „Ius et Lex” 2002, vol. I, nr 1, s. 35-50. 
w sposób bezwzględny słuszności określonego światopoglądu”60. Radbruch otwarty jest więc na różne poglądy i stanowiska, jednak żadnemu z nich nie odmawia apriorycznie możliwości realizacji. Jedynym ograniczeniem tej otwartości jest ten wymiar jego relatywizmu, który zakłada konieczność „ograniczenia możliwości swobodnego stanowienia prawa, zobowiązując do gwarancji określonych wolności człowieka"61. Uważam zatem relatywizm aksjologiczny G. Radbrucha za w pełni uzasadnialny i najlepiej oddający istotę wartości, nie może on jednak być utożsamiany z relatywizmem prezentowanym przez M. Webera. Relatywizm Radbrucha w pełni koresponduje, a nawet jest zgodny w liberalizmem, czego nie da się orzec o relatywizmie M. Webera. Najpełniej i najbardziej klarownie istotę relatywizmu Radbrucha oddaje następująca jego wypowiedź: „relatywizm jest warunkiem demokracji, bowiem ustrój ten nie utożsamia się z żadną określoną koncepcją polityczną. [...] Relatywizm uczy zdecydowania i konsekwencji wobec własnego stanowiska oraz sprawiedliwości wobec cudzego punktu widzenia"62.

\section{Wartości jako podstawa norm}

Prawo jako zjawisko złożone, wieloaspektowe i dynamiczne ${ }^{63}$ może być badane na różnych jego płaszczyznach urzeczywistniania się: tworzenia, obowiązywania, przestrzegania, stosowania i egzekwowania. Równocześnie poddanie analizie prawa na każdym z tych etapów może obejmować inny wymiar prawa: psychologiczny, socjologiczny i/lub aksjologiczny. Przedmiotowe rozważania zawężone zostały do etapu tworzenia regulacji prawnej w jej wymiarze aksjologicznym. Jak słusznie bowiem zauważa K. Pałecki, „,aksjologiczne przekonania i preferencje instytucji normotwórczej, np. legislatora, niekoniecznie są takie same, a nawet $\mathrm{w}$ ogóle możliwe do uzgodnienia z przekonaniami i preferencjami tych, dla których ustanawia się

${ }^{60}$ M. Szyszkowska, Teoria i filozofia prawa, Dom Wydawniczy Elipsa, Warszawa 2008, s. 189.

${ }^{61}$ Ibidem, s. 190. Jest to zdaniem M. Szyszkowskiej przejaw przyjęcia przez Radbrucha - w pewnym zakresie - agnostycyzmu I. Kanta.

62 Ibidem.

${ }^{63}$ E. Kustra, Polityczne problemy tworzenia prawa, Wydawnictwo im. Mikołaja Kopernika, Toruń 1994, s. 5-6; zob. także Ph. Nonet, Ph. Selznick, Law and Society in Transition. Towards Rensponsive Law, New York 1978; G. Teubner, After Legal Instrumentalism: Strategic Models of Post-Regulatory Law; idem, Juridification of Social Spheres, (w:) Juridification of Social Spheres. A Comparative Analysis in the Areas of Labour, Corporate and Social Welfare Law, red. G. Teubne, Berlin-New York 1987; S. Ehrlich, Dynamika norm, PWN, Warszawa 1988; J. Kurczewski, O badaniu prawa w naukach społecznych, Warszawa 1977; G. Skąpska, Prawo a dynamika społecznych przemian, Wydawnictwo UJ, Kraków 1992; K, Pałecki, Prawo a dynamika społecznych przemian, Kraków 1992; idem, Prawo. Polityka. Władza, op.cit. 
normy. Zatem aksjologiczna adekwatność wprowadzanych w procesie normotwórczym norm wyznacza kolejną granicę dla regulacji normatywnej - granicę aksjologiczną"64. Aspekt aksjologiczny, czyli rekonstrukcja granic aksjologicznych regulacji prawnogospodarczych, jest najistotniejszy, ponieważ odgrywając decydującą rolę na etapie tworzenia prawa, tak naprawdę przesądza o zakresie i treści prawa na kolejnych etapach jego urzeczywistniania się. Ponadto przekroczenie granic aksjologicznych przez prawodawcę $\mathrm{w}$ wyniku nieuzgodnienia $\mathrm{z}$ adresatami prawa zespołu wspólnych wartości, dla których obie ze stron domagają się prawnej ochrony, jak też uregulowanie innych poza uzgodnionymi wartościami może skutkować społecznym odrzuceniem tak ustanowionych norm jako następstwem zakwestionowania podstawy aksjologicznej określonych regulacji prawnych przez ich adresatów.

Zdaniem J. Zajadło to właśnie „w perspektywie płaszczyzny aksjologicznej rodzi się z jednej strony pytanie o idealny system prawa [...], z drugiej zaś o ideały ucieleśnione w poszczególnych normach prawnych [...]"65. Istniejący zatem, prawie od zawsze, problem aksjologicznej podstawy wszelkich tworzonych regulacji prawnych gospodarki, sprowadzający się do tego, że zarówno adresaci tworzonych regulacji, jak i sami twórcy postulują oparcie prawa na określonych wartościach, nie zaowocował dotychczas uzgodnieniem wspólnego kanonu pożądanych wartości. Najtrafniej problematykę tę we współczesnej literaturze podsumował P. Dutkiewicz, stwierdzając, iż „prawo - samo nie będąc wartością autonomiczną - musi mieć konieczne i pewne oparcie w wartościach uznawanych w społeczeństwie. Stara paremia rzymska głosi: »Leges sine moribus vanae - prawo jest bezsilne, jeśli nie znajduje oparcia w moralności, w nawykach społeczeństwa "66.

\section{Problematyka moralnej zawartości prawa}

Najbardziej obiecującym podejściem do kwestii regulowania gospodarki prawem wydaje się być podejście zakładające posługiwanie się prawem jako funkcją jego wartości, tzn. wartości, z których ono wyrasta, które ma za zadanie ochraniać, służyć ich osiąganiu, a także pomnażaniu. Oczywiście należy w tym miejscu wspomnieć, że nie istnieje jakaś abstrakcyjna i całkowicie autonomiczna gospodarka oderwana od człowieka i wartości, a przede wszystkim moralności. Uważam, że wszelka działalność gospodarcza niejako z konieczności podlega prawu moralnemu i ocenie moralnej,

\footnotetext{
${ }^{64}$ K. Pałecki, Prawoznawstwo..., op.cit., s. 158.

${ }^{65}$ J. Zajadło, Idea (ideał) prawa, (w:) Leksykon współczesnej... , op.cit., s. 121.

${ }^{66}$ P. Dutkiewicz, op.cit., s. 117.
} 
gdyż zawsze jest konsekwencją określonych ludzkich decyzji. W pełni przychylam się do stanowiska O. Höffego, który zauważa, iż „istnieją zagadnienia moralne, które nie obchodzą ani państwa, ani prawa; nie wynika z tego jednak, że cała moralność jest res privata”67. Autor ten - podobnie jak G. Radbruch - uważa, że „ideą przewodnią państwa i prawa jest sprawiedliwość" ${ }^{68}$, a czymże innym, jeśli nie wartością moralną jest właśnie sprawiedliwość?

Dlatego tak ważne jest wzmocnienie i upowszechnienie zasad tzw. etyki gospodarczej, którą rozumiem jako naukę o moralnych zachowaniach człowieka wytwarzającego i pomnażającego dobra i wartości. M. Ossowska uważała, że „ekonomiczne determinanty mogą stanowić ważny [...] czynnik kształtujący ludzką postawę moralną" ${ }^{69}$. Rozwój moralny każdego człowieka dokonuje się bowiem w społecznym otoczeniu, a nie w oderwaniu od niego, dlatego też przebieg i efekt tego rozwoju warunkowany jest w dużym stopniu przez czynniki ekonomiczne, wyznaczające i ograniczające zarazem aktywność i zakres wyborów jednostki ${ }^{70}$. Oczywisty jest bowiem fakt, że nikt nie będzie przestrzegał prawa tylko i wyłącznie $\mathrm{z}$ uwagi na potencjalnie mogące go dotknąć sankcje negatywne. To nie strach, ale właśnie moralność jest tym czynnikiem, dzięki któremu prawo może funkcjonować, i to w sposób efektywny (skuteczny) ${ }^{71}$. Podobnie uważał sam G. Radbruch, stwierdzając, iż „tylko moralność prawa pozwala na uzasadnienie zobowiązującej mocy prawa. Z norm prawnych jako imperatywów, przejawów woli można [...] wyprowadzać być może przymus [...], nigdy jednak powinnośćc ${ }^{72 "}$.

Słusznie prognozuje filozof moralności Jacquec Monod, iż „żadne społeczeństwo nie przetrwa bez kodeksu moralnego, opartego na wartościach rozumianych i respektowanych przez większość jego członków"73. To właśnie do moralności odwołujemy się wówczas, gdy prawo pozytywne okazuje się być bezradne lub niewystarczające, moralność tę rozumiejąc najczęściej jako normy prawa natury ${ }^{74}$. Różne koncepcje prawa natury zbieżne są bowiem w kwestii postaw jednostek wobec prawa. Koncepcje te postulują postawę „wartościującą wobec prawa”. Odwołują się one do istnienia zarówno związków, jak i odrębności zachodzących między systemem

67 O. Höffe, Etyka państwa i prawa, Znak, Kraków 1992, s. 5.

68 Ibidem, s. 7.

${ }^{69}$ M. Ossowska, Socjologia moralności. Zarys zagadnień, PWN, Warszawa 2005, s. 48.

70 Tak samo L. Krzywicki, Rozwój moralności, „Świat i Człowiek” t. II, Warszawa 1905, s. 837-885, podaję za: M. Ossowska, ibidem, s. 106.

${ }^{71}$ Por. M. Zdyb, Publiczne prawo gospodarcze, Zakamycze, Kraków 1999, s. 73.

72 G. Radbruch, Rechtsphilosophie, „GRGA” Vol. 2, s. 268, podaję za: J. Zajadło, Formuła Radbrucha..., op.cit., s. 165.

73 Zob. J. Russ, Współczesna myśl etyczna, Instytut Wydawniczy PAX, Warszawa 2006, s. 18.

74 Por. M. Ossowska, op.cit., s. 100. Ossowska stwierdza także, że „poczucie prawne” jest tożsame z „poczuciem moralnym” jednostki. A zatem bez uwzględnienia moralności nie można efektywnie i skutecznie tworzyć i posługiwać się prawem. 
norm moralnych a systemem norm prawnych. K. Opałek i J. Habermas uważali, iż oba wymienione systemy normatywne są "nawzajem się uzupełniającymi rodzajami norm zachowania" ${ }^{75}$. Ponadto w odniesieniu do prawodawcy postawa względem prawa przejawiać ma się w przedsięwzięciu aktywnych działań służących zapewnieniu integralności tworzonego prawa, rozumianej jako jego spójność aksjologiczna, przede wszystkim moralna ${ }^{76}$.

Podobnie zatem jak R. Dworkin uważam, że warunkiem zarówno adekwatności (przystawalności) do rzeczywistości gospodarczej, jak i efektywności prawoznawstwa jest „potraktowanie go [prawoznawstwa - przyp. mój, A.K.P.] jako zbioru zagadnień moralności"77. Trafne jest bowiem założenie poczynione przez R. Dworkina, iż „zagadnienia prawoznawcze dotyczą w swej istocie problematyki zasad moralnych, a nie prawnego faktu czy strategii"78. Przyjęcie takiego rozumienia prawoznawstwa, w tym problematyki tworzenia prawa, pozwala uznać, że wartości i normy moralne są koniecznym elementem każdej tworzonej regulacji prawnej, a zatem przyjmujemy niepozytywistyczną koncepcję prawa ${ }^{79}$.

\section{Wartości jako podstawa oraz limitacja działań prawotwórczych}

W przeciwieństwie do A. Batora odrzucam możliwość inicjowania procesów gospodarczych przez „system prawny jako układ pozytywny i dynamiczny” - działanie takie uważam za zakłócające proces gospodarowania i skutkujące dysfunkcjonalnością obu elementów tego układu, czyli zarówno prawa, jak i gospodarki ${ }^{80}$. Przyjmuję natomiast za R. Stammlerem, że życie gospodarcze jest najważniejszym elementem konstytuującym społeczeństwo. Nie do zaakceptowania jednak jest już twierdzenie, że „jego formą jest prawo, które wpływa na prawidłowości życia

\footnotetext{
${ }^{75}$ K. Opałek, Studia z teorii i filozofii prawa, Wydawnictwo UJ, Kraków 1997, s. 37.

${ }^{76}$ Por. M. Zirk-Sadowski, Wstęp, do: R. Dworkin, Imperium prawa, Wolters Kluwer, Warszawa 2006, s. $22-25$.

77 Por. R. Dworkin, Biorac prawa poważnie, PWN, Warszawa 1998, s. 29.

78 Ibidem. Zob. także H. Izdebski, Fundamenty współczesnych państw, Wydawnictwo Prawnicze LexisNexis, Warszawa 2007, s. 8 i n.

${ }^{79}$ Stanowisko takie jest dominujące we współczesnej niemieckiej filozofii prawa. Przyjmowane jest głównie pod wpływem formuły Radbrucha. Zob. K. Opałek, op.cit., s. 40. Szerzej zob. J. Zajadło, Przyszłość dziedzictwa..., op.cit.

80 „System prawny może więc wspierać, a nawet inicjować procesy gospodarcze i będzie to układ pozytywny oraz dynamiczny o charakterze sprzężenia zwrotnego albo też w przeciwnym razie - dysfunkcjonalny o skutkach zdecydowanie negatywnych". A. Bator, Użycie normy prawnej w regulacji stosunków gospodarczych, Kolonia Limited, Wrocław 2000, s. 14-15.
} 
gospodarczego oraz warunkuje całokształt życia społecznego" ${ }^{\text {81 }}$. Prawo jest bowiem tym elementem, który pojawia się wtórnie wobec niewystarczalności innych systemów normatywnych w warunkowaniu procesów gospodarczych, które są samoistne, $\mathrm{w}$ ograniczonym stopniu przewidywalne, złożone, trudne do zdiagnozowania w krótkim horyzoncie czasowym z uwagi na opóźnione występowanie końcowych rezultatów, a przede wszystkim niepoddające się wprost sterowaniu, zwłaszcza przy użyciu norm prawnych.

Tak jak Gustaw Radbruch uważam, że ustawa (czyli prawo typu lex) powinna określać tylko to, co już wcześniej było prawem (prawem w znaczeniu ius) ${ }^{82}$. Prawo w stosunku do materii, którą będzie chciało apriorycznie stymulować i regulować, będzie prawem nieadekwatnym. Nie istnieje bowiem możliwość apriorycznego wskazania wszystkich, czy tylko niektórych mogących pojawić się sytuacji, które wymagać będą poddania ich ochronie prawnej ${ }^{83}$. Prawodawca nie jest także w stanie przewidzieć okoliczności tych sytuacji, ich przebiegu oraz skutków, jakie wywołają. Działania prawotwórcze są w odniesieniu do systemu gospodarczego oparte przede wszystkim na spekulacjach. Jedną z niewielu potwierdzających się właściwości systemu gospodarczego, która dawać może prawodawcy ograniczoną podstawę antycypacji przebiegu procesów gospodarczych, jest cykliczność faz procesów gospodarczych, określona w nauce ekonomii teorią cyklu koniunkturalnego ${ }^{84}$. Jest to jednak bardzo ogólny i niewystarczający w aspekcie uwarunkowań działalności prawotwórczej prawodawcy punkt odniesienia i horyzont planowania jego działań.

Jeżeli podejmuje się próbę badania prawa, zwłaszcza na etapie jego tworzenia, to konieczne staje się - jak słusznie zauważył F. Longchamps - przede wszystkim odpowiedzenie na pytanie, jakie wartości stanowią podstawę systemu prawa oraz w jaki sposób są przez ten system spełniane ${ }^{85}$. Trafnie stwierdza M. Zdyb, że „rozpatrywanie prawa pozytywnego bez próby jego aksjologicznego uzasadnienia sprowadza

${ }^{81}$ M. Szyszkowska, Europejska filozofia prawa, C.H. Beck, Warszawa 1995, s. 26.

82 Szerzej zob. G. Radbruch, Ustawa i prawo, tłum. J. Zajadło, „Ius et Lex” 2002, vol. I, nr 1, s. 160 (159-163). Źródło: G. Radbruch, Rechtsphilosophie III, (w:) Gesamtausgabe, oprac. W. Hassemer, Heidelberg 1990, s. 96-100.

${ }^{83}$ Pogląd taki formułował m.in. H. Kantorowicz. Patrz. J.M. Kelly, Historia zachodniej teorii prawa, Wydawnictwo WAM, Kraków 2006, s. 386-392.

${ }^{84}$ Szerzej na temat teorii cyklu koniunkturalnego w gospodarce zob. Elementarne zagadnienia ekonomii, red. R. Milewski, Wydawnictwo Naukowe PWN, Warszawa 1995, rozdz. XII, zwłaszcza pkt 1.4. Autorzy negatywnie oceniają dokonywanie przez państwo działań mających modyfikować przebieg procesów gospodarczych. „[...] wskazuje się, że państwo nie tylko nie jest w stanie zapewnić zrównoważonego wzrostu gospodarczego, ale przez swoją ingerencję może się stać wręcz generatorem wahań cyklicznych. Stąd płyną postulaty ograniczenia ingerencji państwa w procesy gospodarcze", ibidem, s. 233-234. Państwo oznacza tutaj także prawodawcę, zaś pojęcie ingerencji jest używane sensu largissimo, obejmując każdy rodzaj interwencji, w tym ingerencję prawną.

85 F. Longchamps, Z problemów poznania prawa, Ossolineum, Wrocław 1968, s. 13. 
go na pozycje czysto instrumentalne" ${ }^{\text {"6 }}$. W moim przekonaniu może to skutkować w skrajnych wypadkach nawet nihilizmem ${ }^{87}$ aksjologicznym. W kontekście tych twierdzeń J. Zajadło stawia bardzo ważne, a zarazem trudne pytanie: „Jak dalece filozofia prawa może ingerować w proces ustawodawczy, w treść aktu prawnego? Innymi słowy, gdzie jest granica między filozofią prawa jako nośnikiem niezbędnej dla każdego systemu normatywnego aksjologii a filozofią prawa jako zbędnym balastem utrudniającym proces wykładni?"s8.

To właśnie z uwagi na skomplikowanie i złożoność procesów gospodarczych trudno wyznaczyć empiryczne granice ingerowania prawem w gospodarkę. Jedynym, jak się wydaje niebudzącym sporów sposobem wyznaczenia granicy dla prawodawcy wkraczającego z regulacja prawną na grunt gospodarki, jest próba stworzenia pewnej idealnej wizji tejże granicy oraz idealnego modelu samego prawa oraz systemu gospodarczego. Przywołując dualistyczne znaczenie ideałów w ogóle, J. Zajadło wskazuje na ich charakterystyczne znacznie w odniesieniu do prawa: „znaczenie ideałów w ogóle może mieć wymiar:

- transcendentny (model platoński) - w odniesieniu do prawa oznacza to jakiś ideał zewnętrzny w stosunku do prawa realnie istniejącego,

- immanentny (model arystotelesowski) - w odniesieniu do prawa oznacza to ideał wewnętrzny ucieleśniony w sposób bardziej lub mniej doskonały w samym realnie istniejącym prawie" ${ }^{39}$.

\footnotetext{
${ }^{86}$ M. Zdyb, op.cit., s. 73; por. także M. Dziewulski, Credo, „Znak” 1990, nr 10-11, s. 29.

${ }^{87}$ F. Nietzsche uważał, że nihilizm jest wytworem czasów nowożytnych. J. Russ rozwija to twierdzenie, zauważając, że „śmiertelną chorobą naszej epoki jest nihilizm, panowanie Absurdu, Niczego...”. Zob. J. Russ, op.cit., s. 23.

${ }_{88}^{8}$ J. Zajadło, Gesetz und Recht, op.cit., s. 48.

${ }^{89}$ J. Zajadło, Idea (ideał) prawa, op.cit., s. 121.
} 


\section{Idea prawa Gustawa Radbrucha jako idealna "granica" procesu prawodawczego}

\section{Ogólne rozważania dotyczące idei prawa}

W literaturze polskiej koncepcjom G. Radbrucha sporo uwagi poświęcili Cz. Znamierowski ${ }^{90}$, G.L. Seidler ${ }^{91}$, J. Wróblewski ${ }^{92}$ oraz J. Stelmach ${ }^{93}$, a w najnowszej literaturze (z XXI wieku) koncepcje G. Radbrucha przybliżyli polskiemu czytelnikowi M. Szyszkowska oraz J. Zajadło.

W swych koncepcjach Gustaw Radbruch nawiązuje do filozofii I. Kanta. Uznawany jest za jednego z twórców tzw. szkoły heidelberskiej neokantyzmu, która obok szkoły marburskiej odegrała znaczącą rolę w nauce prawa w XX wieku. Wspólną podstawą neokantyzmu jest rozróżnienie „tego, co jest” od „tego, co być powinno” (tzw. teza o rozłączności, inaczej: metoda dualizmu). Jednak dla Radbrucha taka dychotomia była niewystarczająca. W miejsce neokantowskiego dualizmu Radbruch wprowadza trializm metodologiczny ${ }^{94}$. Wartością jest zatem idea prawa, która dzięki przyjętemu trializmowi staje się zjawiskiem kultury. Zdaniem J. Zajadło przyjęty przez G. Radbrucha trializm metodologiczny „przenosi się także na ideę prawa, która [...] ma strukturę trójelementową: sprawiedliwość, celowość i bezpieczeństwo

90 C. Znamierowski przełożył na język polski Rechtsphilosophie - Filozofię prawa. Książka wydana została w 1938 roku przez Księgarnię Powszechną, w ramach „Biblioteki Umiejętności Prawnych i Politycznych”, pod red. A. Milera i S. Tylbora. Przełożył także artykuł G. Radbrucha O celu prawa, który ukazał się w numerze 3 „RPEiS” z roku 1937.

91 G.L. Seidler zajął się relatywizmem G. Radbrucha przejawiającym się w założeniu, że prawo należy rozpatrywać na płaszczyźnie racjonalno-logicznej, czyli traktującym prawo jako wyraz przyjęcia określonych wartości, ale jednocześnie odmawiającego nauce prawa możliwości dokonania między nimi wyboru, ponieważ jest to sprawa osobistego przekonania. Zob. G.L. Seidler, Doktryny prawne imperializmu, Wydawnictwo Lubelskie, Lublin 1979, s. 225-228.

92 J. Wróblewski w Zagadnieniach teorii wykładni prawa ludowego przy omawianiu roli celu w wykładni prawa oraz analizując poglądy na temat wartości - celów, jakim prawo powinno służyć, odwołał się do artykułu G. Radbrucha O celu prawa. Zob. J. Wróblewski, Zagadnienia teorii wykładni prawa ludowego, Wydawnictwo Prawnicze, Warszawa 1959, s. 357, przypis 11.

93 J. Stelmach w monografii Współczesna filozofia interpretacji prawniczej odwołuje się do zbiorowego wydania dzieł G. Radbrucha z lat 1987-1990, przypisując Radbruchowi zasługę w tym, że unaocznił jak wielki i silny jest rozdźwięk pomiędzy stanowiskami prawnonaturalnymi i pozytywistycznymi. Zob. J. Stelmach, Wspótczesna filozofia interpretacji prawniczej, Wydawnictwo UJ, Kraków 1999, s. 32.

${ }_{94} \mathrm{Na}$ jego podstawie wyróżniamy w dyscyplinach naukowych: 1) socjologię prawa, która zajmuje się empirycznym wyjaśnianiem rzeczywistości prawa; 2) filozofię prawa, jako naukę o wartościach w prawie, które bada prawo takim, jakie ono być powinno; 3) prawoznawstwo obejmujące dogmatykę prawa, która zajmuje pozycję pośrednią. Z jednej strony opiera się na prawie pozytywnym i bada, na ile ono jest społecznie skuteczne, a z drugiej strony skupia się na treści prawa, na tym, jakie ono być powinno, co przejawia się w interpretacji prawa m.in. przez uwzględnienie celowości, czyli słuszności prawa. 
prawne"95. Autor przytacza także pogląd A. Kaufmanna, którego zdaniem tym trzem wartościom „w politycznej rzeczywistości odpowiadają autorytet, korzyść i gwarancja państwa" ${ }^{\prime 96}$. Relacja pomiędzy tymi trzema wartościami jest każdorazowo określana przez dany system instytucjonalno-prawny ${ }^{97}$

W tej trójelementowej idei prawa Radbrucha można odnaleźć wpływ myśli I. Kanta, bowiem Radbruch uważa, że istotą i obowiązkiem prawa jest realizacja zarówno każdej z tych wartości, jak i całej idei ${ }^{98}$. Drugim elementem świadczącym o recepcji twierdzeń I. Kanta jest „oparcie idei prawa na zasadzie celowości, w przeciwieństwie do zasady przyczynowości panującej w naukach przyrodniczych"99. Radbruch przyjął jednak za R. Stammlerem, a w przeciwieństwie do Kanta, odróżnienie koncepcji prawa od idei prawa ${ }^{100}$.

G. Radbruch dokonał także rozróżnienia postaw, jakie na gruncie określonych nauk są przyjmowane wobec wartości. Wyróżnił trzy postawy:

” postawę »odnoszącą się do wartości charakterystyczną dla nauk prawnych,

- postawę "wartościującą" cechującą filozofię prawa oraz

- postawę »ślepą wobec wartości« - tutaj G. Radbruch napisał »vacat«"101.

Przy postawie trzeciej - jak pisze J. Zajadło - zdaniem Kastnera mógł Radbruch wskazać na socjologię prawa ${ }^{102}$. Stanowisko B. Kastnera nie jest możliwe do przyjęcia, ponieważ socjologia prawa w swoich badaniach zajmuje się wartościami: tworzy ich definicje, różnicuje je, dokonuje ich typologii, bada stopień uwzględniana przez prawodawcę społecznie podzielanych wartości w tworzonych regulacjach prawnych, bada stopień i zakres zmienności wartości; czyli przedmiotem jej zainteresowania jest szeroko rozumiana aksjologia prawa. Socjologia prawa przyjmuje bowiem założenie - czynił tak m.in. F. Znaniecki - że jeżeli teoria jakiejkolwiek nauki ma służyć ludziom, to musi być zorientowana na te wartości, które są dla nich szczególnie cenne i od których realizacji uzależniony jest całokształt ich życia ${ }^{103}$.

95 J. Zajadło, Formuła Radbrucha..., op.cit., s. 147.

96 J. Zajadło, Dziedzictwo przeszłości..., op.cit., s. 99; zob. idem, Formuła Radbrucha..., op.cit., s. 147; idem, Bezpieczeństwo - Celowość - Sprawiedliwość: Antynomie idei prawa, „Gdańskie Studia Prawnicze”, t. IX, Gdańsk 2002, s. 239.

97 Zob. M. Szyszkowska, Teoria i filozofia prawa, op.cit., s. 188.

98 Por. I. Gołowska, op.cit., s. 151 i n.

99 Ibidem, s. 152. Podobne twierdzenie na temat koncepcji R. Stammlera zob. R.A. Tokarczyk, Filozofia prawa w perspektywie prawa natury, Temida 2, Białystok 1997, s. 111.

100 Ibidem, s. 111: „Ideę prawa Stammler pojmował jako realizację sprawiedliwości polegającej na osiąganiu harmonii współżycia społecznego, »wspólnoty obdarzonych wolnością jednostek«, w której jednostka ludzka podporządkowuje swoje cele celom wspólnoty”.

101 J. Zajadło, Formuła Radbrucha..., op.cit., s. 143 i 145.

102 Ibidem.

103 Por. F. Znaniecki, Czy socjologowie powinni być także filozofami wartości?, (w:) idem, Pisma filozoficzne, t. 1, PWN, Warszawa 1987, s. 468. 


\section{Idea prawa a pojęcie prawa}

Według G. Radbrucha prawo jest czymś, co jest nam dane (Gegebenheit), a to stwierdzenie ma ten sens, że wskazuje nam ideę, której prawo ma obowiązek służyć. Zadaniem prawa jako tworu kulturowego i konwencjonalnego jest realizowanie idei prawa. Radbruch pisał, że „pojęcie prawa jest pojęciem kulturowym, tzn. pojęciem rzeczywistości zorientowanej na wartości, której sensem jest służenie wartościom. Prawo jest rzeczywistością, której sensem jest służenie wartościom prawa, idei prawa" ${ }^{\prime 104}$. Natomiast sama idea prawa ma charakter aprioryczny i przedprawny (przedjuryczny) ${ }^{105}$.

Zdaniem J. Zajadło problematyka wartości pojawia się w koncepcji Radbrucha pod wpływem E. Laska, „a w konsekwencji (także) problem relacji pomiędzy ideą prawa a pojęciem prawa oraz antynomie i konflikty wartości wewnątrz idei i celów prawa” ${ }^{106}$. Zdaniem J. Oniszczuka Radbruch samodzielnie jednak stwierdził, że „filozofia prawa stawia kwestię wartości, które uzasadniają dodatnio porządek prawny jako sprawiedliwy, a prawo jako słuszne"107.

G. Radbruch używał pojęcia idei prawa w ścisłym związku z pojęciem sprawiedliwości. Pojęcia sprawiedliwości nie używał w jednym ustalonym znaczeniu, ale w dwóch znaczeniach: węższym i szerszym ${ }^{108}$. Idea prawa jest przez autora utożsamiana ze sprawiedliwością sensu largo. Na ideę tę składają się trzy elementy:

Sprawiedliwość - sensu stricte, której emanacją jest równość. Równość, która stanowi abstrakcję od rzeczywistej nierówności. Po drugie, sposobem osiągania owej równości jest proporcjonalność. Sprawiedliwość wyznacza formę prawa. Jest uznawana przez Radbrucha za wartość absolutną. Dokonując współcześnie interpretacji poglądów G. Radbrucha, a odwołując się przy tym do twierdzeń formułowanych współcześnie w prawoznawstwie (np. zgodnie z koncepcją K. Pałeckiego - nie istnieją wartości absolutne), przyjmuję, że Radbruchowi chodziło raczej o to, że sprawiedliwość jest wartością naczelną triady, co przejawia się w bezwyjątkowym podejściu do jej realizacji. Zdaniem J. Oniszczuka wartość sprawiedliwości jest przez Radbrucha rozumiana jako „zasada formalna, określa formę prawa, występuje w postaci równego traktowania równych praw i nierównego traktowania nierównych"109.

104 J. Zajadło, Dziedzictwo przeszłości..., op.cit., s. 90.

105 J. Oniszczuk, Filozofia i teoria prawa, C.H. Beck, Warszawa 2008, s. 323.

106 J. Zajadło, Dziedzictwo przeszłości..., op.cit., s. 89.

107 J. Oniszczuk, Filozofia i teoria prawa..., op.cit., s. 323.

108 Tak uważał B. Kastner. Jego poglądy przytacza J. Zajadło, Dziedzictwo przeszłości... , op.cit., s. 101-102; zob. idem, Formuła Radbrucha... , op.cit., s. 149-150.

109 Ibidem, s. 323-324. 
Celowość to ten element idei, który wyznacza i kreuje treść prawa. Treść prawa odnosi się do takich kwestii, jak: interesy twórców prawa i adresatów prawa, oczekiwania i potrzeby obu tych grup, a także do kwestii tego, co powinno czy też co może być uregulowane przy użyciu prawa. Poszczególne cele prawa tworzą przy tym dialektyczny związek. Celowość jest wartością o doniosłym znaczeniu zarówno dla problematyki prawnej, jak i powiązanej z nią problematyki politologicznej. Uważał tak sam G. Radbruch, stwierdzając: „Ponieważ prawo w swojej istotnej części tożsame jest $\mathrm{z}$ wolą państwa, a państwo $\mathrm{w}$ swym istotnym wymiarze jest instytucją prawną, pytanie o cel prawa wiąże się ściśle z pytaniem o cel państwa" ${ }^{110}$. Z kolei cele państwa i prawa mają istotny wpływ na to, jakie cele będzie mogła urzeczywistniać jednostka w państwie, w którym żyje, oraz na podstawie adresowanego do niej prawa, które może nałożyć na nią ograniczenia w tej materii. Bowiem właśnie wybierając określone cele, jednostka ma nadzieję na zrealizowanie najważniejszych dla niej wartości. Trafnie ujmuje to J. Oniszczuk, twierdząc, że „ludzie mają aspiracje do osiągania tych celów, zwłaszcza odpowiadających wartościom wysoko usytuowanym w hierarchii. W każdym razie tak określone cele, zwłaszcza jeśli są powszechnie aprobowane przez daną zbiorowość, stanowią odniesienie do ludzkich dążeń" ${ }^{111}$.

Bezpieczeństwo zostało zawężone do kategorii bezpieczeństwa prawnego, dzięki czemu cała idea staje się bardziej użyteczna i adekwatna dla moich rozważań. Bezpieczeństwo prawne jest tutaj synonimem przewidywalności i pewności prawa (rozumianej jako stabilność). W przeciwieństwie do sprawiedliwości nie jest wartością absolutną. Na istotne znaczenie bezpieczeństwa wskazuje G. Skąpska, pisząc: „Koncepcja pewności i bezpieczeństwa wymaga też jasnego postawienia problemu pewności i bezpieczeństwa autonomicznych działań organów stosujących prawo. Koncepcja ta wymaga wprowadzenia problematyki sfery wyłączonej z ingerencji państwa, sfery wolnej od przymusu, której granice są wyznaczone, ściśle zagwarantowane i chronione przez istniejący porządek prawny"112.

Bezpieczeństwo prawne, sprawiedliwość oraz celowość są nie tylko ideami wartościującymi, czyli przekonaniami dotyczącymi tego, co dana jednostka powinna uznać za wartość. Są one szczególnym rodzajem wartości: wartościami - celami. Idee wartości (bezpieczeństwa prawnego, sprawiedliwości i celowości) stanowią również „abstrakcyjne wartości powszechne", ponieważ są oderwane od realnych przedmiotów ${ }^{113}$.

\footnotetext{
110 G. Radbruch, Filozofia prawa, Wydawnictwo Naukowe PWN, Warszawa 2009, s. 58.

111 Wspótczesne państwo w teorii i praktyce. Wybrane elementy, red. J. Oniszczuk, Oficyna Wydawnicza SGH, Warszawa 2008, rozdz. VII, pkt 4, s. 252.

112 G. Skąpska, op.cit., s. 37 oraz 48-49.

113 J. Oniszczuk, Kultura i wartości prawne, „Zeszyty Naukowe WSZiP im. H. Chodkowskiej” rok XI, z. 2 (23), ,Zeszyt Prawniczy” IV, Warszawa 2006, s. 21.
} 
Zgodnie zaś z koncepcją G. Radbrucha „prawo jest rzeczywistością, która swój sens i znaczenie czerpie stąd, że służy swoistej wartości [...] - ideałowi prawa"114. Służyć więc ma właśnie tym trzem połączonym ze sobą wartościom.

Wydawać by się mogło, że naczelną ideą jest sprawiedliwość, z niej bowiem autor wyprowadza celowość prawa, bezpieczeństwo i sprawiedliwość w węższym tego słowa znaczeniu, przychylam się jednak do zdania tych autorów, którzy twierdzą, że „jądrem” tej trójelementowej idei jest celowość. Jak słusznie stwierdza J. Zajadło, „trzeba pamiętać, że tak pojęta celowość była również dla Radbrucha rodzajem sprawiedliwości" ${ }^{115}$. Przy rozważaniach o koncepcji idei prawa G. Radbrucha na pojęcie sprawiedliwości w dwoistym (szerszym i węższym znaczeniu) zwrócił uwagę A. Kaufmann (Problemgeschichte der Rechtphilosophie). Wskazał, że gdy Radbruch używa pojęcia sprawiedliwości w szerszym tego słowa znaczeniu, to ma na myśli celowość prawa, bezpieczeństwo prawne i sprawiedliwość w węższym znaczeniu. Znaczy to, że po pierwsze: celowość w prawie ujmuje się jako pojęcie odwołujące się do treści prawa, a kryterium jego jakości jest słuszność prawa. Po drugie, że bezpieczeństwo prawne w założeniu swym zakłada istnienie prawa pozytywnego, a więc stanowionego w formie aktu prawnego, który obowiązuje, gwarantując bezpieczeństwo i pewność jednostkom. Po trzecie, że sprawiedliwość w tym węższym znaczeniu oznacza równość wobec prawa, czyli prawo do równego traktowania przez władze publiczne, czyli chodzi o sprawiedliwość rozdzielczą (dystrybutywną). Sprawiedliwość w znaczeniu szerokim „oznacza więc ideę prawa w ogóle i w związku z tym prawo słuszne jest nie tylko prawem celowym i równym dla wszystkich, ale i bezpiecznym" ${ }^{\prime 16}$. Natomiast w znaczeniu węższym sprawiedliwość stanowi dla Radbrucha wyłącznie zasadę formalną, którą utożsamia $\mathrm{z}$ równością. Radbruch odwołuje się tutaj do wprowadzonego przez Arystotelesa podziału na sprawiedliwość wyrównawczą i rozdzielczą. $\mathrm{Z}$ tak ujętej przez Radbrucha wartości sprawiedliwości wynika, że jej węższe rozumienie stanowi formę dla prawa, natomiast aby wyposażyć ową formę w treść, zmuszeni jesteśmy wyjść poza sprawiedliwość i posłużyć się wartością celowości ${ }^{117}$.

114 J. Zajadło, Wprowadzenie do wydania polskiego, (w:) G. Radbruch, Filozofia prawa, op.cit., s. XXXII.

115 J. Zajadło, Formuła Radbrucha..., op.cit., s. 148; idem, Dziedzictwo przeszłości..., op.cit., s. 100; idem, Bezpieczeństwo - Celowość..., op.cit., s. 239.

116 J. Zajadło, Dziedzictwo przeszłości..., op.cit., s. 113; idem, Formuła Radbrucha..., op.cit., s. 159; idem, Bezpieczeństwo - Celowość... , op.cit., s. 245.

117 Zob. J. Zajadło, Dziedzictwo przeszłości..., op.cit., s. 101-102. 


\section{Antynomiczny charakter idei prawa a homeostatyczna równowaga triady wartości}

G. Radbruch wykazał, że między trzema wymienionymi wartościami zachodzą różnorodne relacje, a same wartości nie zawsze dają się zharmonizować. J. Zajadło opisuje to następująco: „Koncepcja Radbrucha opiera się na uznaniu możliwości istnienia wewnętrznych antynomii między poszczególnymi elementami idei prawa. Nie są to jednak antynomie o charakterze destrukcyjnym, które prowadzą do unicestwienia systemu prawa. Wręcz przeciwnie, dialektyczny charakter tych konfliktów powinien prowadzić do stałego doskonalenia systemu prawa"118. Zresztą konflikt jest zjawiskiem nieodłącznie towarzyszącym wszelkim przejawom życia społecznego i niekoniecznie należy negatywnie oceniać jego występowania, jak też nie należy czynić starań mających na celu wyeliminowanie wszelkich pojawiających się konfliktów ${ }^{119}$, ponieważ paradoksalnie mają one zdolność kreowania pozytywnych zjawisk. Konflikty, w tym antynomiczność wartości idei prawa, konieczne są do coraz lepszego działania jednostek, efektywniejszego realizowania wartości - celów oraz osiągania przez całą społeczność coraz doskonalszych form.

Nasuwa się wobec tego pytanie, której z trzech wartości w razie ich zbiegu przyznać należy prymat? Bezpieczeństwo prawne wynika z ustawy, która przez swoje obowiązywanie zapewnia prawu stabilność. Natomiast sprawiedliwość zapewnia równość równym, co nie zawsze wynikać musi z ustawy. Gdy więc pojawia się konflikt między bezpieczeństwem prawnym a sprawiedliwością, mamy dylemat trudny do rozwiązania, ponieważ po stronie sprawiedliwości pojawi się także celowość, czyli słuszność prawa. Dylemat ten może okazać się nierozwiązywalny, a wówczas takiego prawa nie będzie można uznać za obowiązujące, a w skrajnych wypadkach nie będzie mogło być w ogóle uznane za prawo. Prawo, które nie realizuje w żadnym stopniu wartości sprawiedliwości, nie jest prawem. Radbruch - zdaniem J. Zajadło - uważa ponadto „za konieczne uznanie, że w pewnych okolicznościach naruszanie elementarnych zasad sprawiedliwości (Recht) podważa nawet formalną legalność określonych norm (Gesetz)"120.

118 J. Zajadło, Wprowadzenie do wydania polskiego, op.cit., s. XXX.

119 Zdaniem B. Polanowskiej-Sygulskiej podobne stanowisko prezentuje I. Berlin. Zob. eadem, Pluralizm wartości i jego implikacje w filozofii prawa, Księgarnia Akademicka, Ośrodek Myśli Politycznej, Kraków 2008, s. 393.

${ }_{120}$ J. Zajadło, Gesetz und Recht, op.cit., s. 42. Opinia ta została w literaturze filozoficznoprawnej określona mianem formuły Radbrucha. 
Elementy idei prawa pozostają ze sobą w antynomii, która nie jest destrukcyjna, lecz dialektyczna. Zdaniem J. Zajadło ten dialektyczny charakter stanowi swoistą wartość, ponieważ „powinien zmierzać do stałego doskonalenia prawa, a zwłaszcza pozwalać na optymalne dopasowanie jego formy i treści do warunków czasu i miejsca stanowienia [...]”21. J. Zajadło uważa, że „w koncepcji Radbrucha relacje pomiędzy trzema elementami idei prawa mają charakter antynomiczny i dopóki możliwe konflikty pomiędzy bezpieczeństwem prawnym, celowością i sprawiedliwością pozostają w granicach homeostatycznej równowagi, dopóty jest zachowana homeostaza systemu prawa jako całości”"122.

Homeostaza ${ }^{123}$ jest $\mathrm{w}$ naukach prawnych pojmowana najczęściej jako stan równowagi. Istota homeostazy bywa określana jako „przywracanie systemu do stanu normalnego po zaistniałych zakłóceniach”124, jednak mimo to nie znajdujemy w literaturze przypadków zamiennego używania pojęć homeostazy i melioryzmu, choć do tej właśnie funkcji - równoważenia, wyrównywania - sprowadza się istota melioryzmu. Natomiast o homeostazie w tym znaczeniu, jakim posługiwał się Radbruch, w polskiej literaturze pisał J. Wróblewski ${ }^{125}$, a współcześnie A. Kozak ${ }^{126}$. Ten ostatni doprecyzował i rozbudował to pojęcie ${ }^{127}$. Pojęcie homeostatycznej równowagi, w jakiej znajdują się wartości idei prawa, nie będzie przedmiotem dogłębnej analizy $\mathrm{w}$ tej pracy, jednak pojęcie to jako element łączący się z poruszaną problematyką wymaga poczynienia kilku uwag.

121 J. Zajadło, Dziedzictwo przeszłości... , op.cit., s. 99-100; idem, Formuła Radbrucha... , op.cit., s. $147-148$.

122 J. Zajadło, Bezpieczeństwo - Celowość... , op.cit., s. 234.

${ }^{123}$ Pojęcie homeostazy zostało po raz pierwszy sformułowane w naukach bioekologicznych przez W.B. Cannona, fizjologa z Harwardu. W.B. Cannon, The Wisdom of the Body, Harward 1932, s. 24, podaję za: I. Bogucka, Funkcje prawa. Analiza pojęcia, Zakamycze, Kraków 2000, s. 41. „Według niego equilibrium to jest pewien stan jakiegoś systemu, który cechuje się określonymi parametrami. Zmiana jednego z tych parametrów nie musi jednak oznaczać dążenia systemu do obniżenia poziomu zmiany [...]. Na oznaczenie efektu procesów, które zachodzą w systemach, przeciwdziałając zmianom, które mogłyby istniejący stan systemu zniszczyć, proponuje on właśnie termin »homeostaza«".

${ }^{124}$ I. Bogucka, op.cit., s. 40.

125 J. Wróblewski, Prawo i homeostaza społeczna, „Państwo i Prawo” 1982, nr 12, s. 30-40.

126 A. Kozak, Homeostaza prawa, (w:) Z zagadnień teorii i filozofii prawa. Autonomia prawa ze stanowiska teorii i filozofii prawa, red. J. Helios, Wydawnictwo UWr., Wrocław 2003.

${ }^{127}$ Przez homeostazę A Kozak rozumie „stan względnej równowagi systemu, gwarantujący jego trwanie w czasie, w mniej więcej ustabilizowanej formie. Wobec koniecznych interakcji każdego takiego systemu z jego otoczeniem, osiągnięcie homeostazy wymaga albo jego przynajmniej względnej autonomii (w sensie »immunizowania " na wpływy zewnętrzne), albo istnienia wewnętrznych mechanizmów korygujących wahania systemu, wywołane przez wpływy zewnętrzne. [...] Homeostazę prawa uważam za fakt dany, dostrzegalny $\mathrm{z}$ wielu punktów widzenia. $\mathrm{W}$ ujęciu diachronicznym widać, że prawo trwa przez pokolenia w stabilnych strukturach instytucjonalnych, będąc trwałym elementem naszej kultury. [...] W perspektywie synchronicznej natomiast można wskazać szereg przesłanek do stwierdzenia, że prawo charakteryzuje się przynajmniej względną autonomią względem innych dziedzin kultury”.

A. Kozak, ibidem, s. 145. 
Należy przy tym zaznaczyć, że owe antynomie nie muszą, ale mogą się pojawić. Dlatego zgadzam się z poglądem J. Zajadło, że „zachowanie homeostazy systemu prawa powinno polegać na właściwym pojmowaniu relacji pomiędzy Dworkinowskimi zasadami i regułami, i to zarówno w procesie stanowienia, jak i stosowania prawa" ${ }^{128}$. Wartości wchodzące w skład triady można utożsamić właśnie z Dworkinowskimi zasadami. Tak samo jak one, wartości triady nie wyznaczają żadnego konkretnego sposobu zachowania prawodawcy czy też adresatów prawa. Mogą być spełniane $\mathrm{w}$ różnym stopniu (nie są bowiem tautologiczne, lecz gradacyjne). Zarówno zasady, jak i wartości triady są szczególnymi normami nakazującymi realizację pewnego stanu rzeczy w możliwie największym stopniu. Oczywiście stopień tego spełnienia uwarunkowany jest możliwościami, jakie wyznacza przede wszystkim system prawny, a w drugim rzędzie są to możliwości faktyczne.

\section{Celowość jako naczelna wartość idei prawa}

W ramach samej idei prawa prymat przyznaję wartości celowości, która powinna być w największym stopniu realizowana spośród pozostałych wartości idei prawa, utożsamianej $\mathrm{w}$ tej pracy $\mathrm{z}$ aksjologiczną granicą regulacji prawa gospodarczego. Zgadzam się bowiem z J. Zajadło, który uważa, że „wnikliwa analiza wszystkich elementów idei prawa i wzajemnych relacji pomiędzy nimi prowadzi jednak do wniosku, że to nie formalnie pojęta sprawiedliwość i bezpieczeństwo prawne, lecz właśnie wypełniona materialną treścią celowość prawa stanowi »jądro Radbruchowskiej filozofii prawa " ${ }^{\prime 29}$. Najbardziej literalne rozumienie celowości to działanie zmierzające do jak najpełniejszego i najbardziej efektywnego osiągnięcia zamierzonej wartości celu. Jednak przy jakiejkolwiek próbie interpretowania pojęcia „celu” ${ }^{130}$ należy bezwzględnie przyjąć imperatyw hipotetyczny I. Kanta, a zatem uznać, iż „tylko człowiek, a wraz z nim każde rozumne stworzenie, jest celem samym w sobie. Jest ono mianowicie, dzięki autonomii swojej wolności, podmiotem prawa moralnego, które

128 J. Zajadło, Gesetz und Recht, op.cit., s. 48.

129 J. Zajadło, Formuła Radbrucha..., op.cit., s. 148. „Według kryterium indywidualizującej, relatywnej, bo zależnej od światopoglądu ustawodawcy, Zweckmäßigkeit prawo jest więc oceniane jako słuszne (richitiges Recht) bądź jako niesłuszne (unrichtiges Recht)".

130 „Zweck prawa (a nie Zeil) mogący oznaczać w języku polskim zarówno »cel«, jak i »zamiar", »intencję«, "powód «, »sens«, w każdym razie znaczący więcej niż konkretny »cel«. Zgodnie z nim dane prawo oceniane jest pod względem swej słuszności (Richtigkeit)". G. Radbruch, Rechtsphilosophie, Leipzig 1932, s. 73, podaję za: D. Bogacz, Formuła i filozofia prawa Gustawa Radbrucha. W zwiazku z ksiażką: J. Zajadało, Formuła Radbrucha... , „RPEiS” rok LXIV, 2002, z. 3, artykuł recenzyjny. 
jest święte"131. Najważniejszym zadaniem celowości jest jednak wyznaczanie treści tworzonego prawa ${ }^{132}$.

Podobnie jak M. Zdyb uważam, że wartością samą w sobie nie jest wolność od prawa, ale poszukiwanie pełnej jego formuły (poszukiwanie treści prawa) ${ }^{133}$. Ustalenie zaś treści prawa zgodnie z założeniami poczynionymi przez G. Radbrucha wymaga odwołania się właśnie do celowości, która o tej treści przesądza. W sprawie przyznania prymatu wartości celowości w ramach idei prawa wypowiada się T. Gizbert-Studnicki, pisząc: „Radbruch odwołuje się do Maksa Webera, twierdząc, że konstrukcja instytucji prawnej sprowadza się do skonstruowania typu idealnego pewnej klasy stosunków społecznych. Skoro przy tym o istotności decyduje idea prawna, konstrukcja instytucji prawnej wymaga odwołania się do świata wartości, w którym powinna być odnaleziona wartość nadająca sens danej klasie stosunków społecznych. Z reguły tą wartością będzie celowość, jako że instytucje prawne konstruowane są zwykle dla realizacji określonego celu” ${ }^{134}$. Można zatem przyjąć, że rola celowości w ramach idei prawa, ergo procesu prawotwórczego, jest nie tylko istotna, ale wręcz przewodnia i rozstrzygająca, bowiem decyduje o tym, „co" w następstwie tego procesu powstanie, czyli jakie treściowo prawo powstanie.

Prymat celowości w regulacji gospodarki daje się uzasadnić na trzy sposoby:

1) gospodarka nie spełnia funkcji gwarancyjnych (rozumianych jako zagwarantowanie ochrony), jak ma to miejsce np. na gruncie stosunków rodzinnych czy karnych, dlatego jej regulowaniu możemy dać prymat takim wartościom, jak efektywność, skuteczność ekonomiczność, innowacyjność, czyli szeroko rozumianej celowości;

2) prawo celowe stwarza warunki równości szans dla wszystkich, co sprawia, że celowość skutkuje osiągnięciem sprawiedliwości;

3) prawo celowe jako równe dla wszystkich jest prawem słusznym; słuszność natomiast skutkuje tym, że prawo zyskuje przymiot bezpiecznego/pewnego - następuje sprzężenie zwrotne między słusznością a pozytywnością prawa.

Przyjmuję, że wartości sprawiedliwości, bezpieczeństwa prawnego i celowości są wartościami autotelicznymi, gdyż stanowią cel dążeń oraz stanowią zasadnicze przesłanki (preferencje) w wyborach dokonywanych przez ludzi, natomiast prawo jest wartością instrumentalną, gdyż służy jedynie do osiągania wartości autotelicznych. Skąd wynikają te trzy wartości? Owe wartości tkwią w moralności każdej jednostki,

${ }^{131}$ I. Kant, Krytyka praktycznego rozumu, PWN, Warszawa 2004, podaję za: J. Hartman, op.cit., s. $256-257$.

132 M. Szyszkowska, Teoria i filozofia prawa, op.cit., s. 188.

133 Ibidem.

134 T. Gizbert-Studnicki, Koncepcje „natury rzeczy” w zachodnioniemieckiej filozofii prawa, „Etyka” 1981, nr 19, s. 139. 
pochodzą z pewnego rdzenia aksjologicznego, który wykształcił się w procesie internalizacji i socjalizacji.

W każdym układzie wartości można dokonać ich hierarchizacji polegającej na wyróżnieniu wartości bardziej i mniej ważnych ze względu na cele stawiane konkretnemu układowi wartości. Uważam, że tak samo postąpić można z triadą Radbruchowską. Jeżeli zastosowaniem dla niej ma być obszar działań podmiotów gospodarujących, wówczas wartością najważniejszą powinna być celowość, następnie sprawiedliwość, a jako ostatnie bezpieczeństwo prawne. Legitymizacją dla przyjęcia takiej hierarchizacji jest fakt - już wcześniej wspomniany - iż szeroko rozumiane prawo gospodarcze nie spełnia tzw. funkcji ochronnej, jak to ma miejsc np. w przypadku prawa karnego, a jedynie funkcje gwarantowania określonych ram działania. Ponadto działalność gospodarcza z istoty swej nastawiona jest na osiąganie pewnych wartości - celów w ramach istniejącego systemu prawnego na zasadzie ryzyka. Dlatego też naturalne wydaje się przyjęcie stanowiska, że kluczową wartością, która powinna być urzeczywistniana w stopniu maksymalnym przez podmioty gospodarujące, jest celowość określająca, jakie cele i w jaki sposób mogą być najpełniej urzeczywistniane.

\section{Podsumowanie}

Nierespektowanie wartości zarówno w procesie stanowienia prawa, jak i w jednostkowych procesach wyboru (np. decyzje inwestorów, decyzje konsumenckie) maksymalizuje ryzyko podejmowania nieefektywnych decyzji i wyborów, przynosząc szkodę w wymiarze społecznym i jednostkowym ${ }^{135}$. W świadomości społecznej ugruntowane jest bowiem przekonanie, że stan prawa decyduje o wiarygodności państwa, instytucji demokratycznych oraz decyduje o jakości życia jednostek ${ }^{136}$. Z tego punktu widzenia jakość stanowionego prawa, a zwłaszcza jego wartość aksjologiczna, ma szczególnie ważne znacznie. Na uwagę zasługuje więc pogląd W. Łączkowskiego, że u podstaw każdego systemu prawa znajduje się określona aksjologia, nawet jeżeli nie jest wprost ujawniana. Autor odrzuca przy tym postulaty odwołujące się do konieczności neutralności aksjologicznej prawa z uwagi na

135 Por. M. Łobocki, Teoria wychowania w zarysie, Kraków 2004, s. 77-95.

136 Jakość życia rozumiana jako poczucie należytego gwarantowania sprawiedliwego ładu społecznego, bezpieczeństwa osobistego, a także bezpieczeństwa prawnego oraz wolności, w tym przede wszystkim wolności gospodarczej. Por. Z. Szonert, Aksjologia służby publicznej oraz stanowienia i stosowania prawa, „Zeszyty Naukowe WSZiP” rok X, 2005, z. 1 (17), s. 23-24. 
fakt, że jest ono adresowane do wszystkich obywateli, wśród których uznawane są różnorodne wartości ${ }^{137}$.

Gdy system norm prawnych jest niespójny, niestabilny, wewnętrznie sprzeczny, wówczas rodzi się pytanie o właściwość i adekwatność podstawy aksjologicznej takiego prawa. Rodzi się także pytanie o to, jak takim prawem się posługiwać, jaką postawę wobec niego przyjąć. To najczęściej prawnicy znajdują się w sytuacji konieczności przyjęcia określonego stanowiska wobec dysfunkcjonalnego - rozumianego jako aksjologicznie niepoprawne - prawa. W sytuacji takiej mają wybór zakładający triadę możliwości ${ }^{138}$ :

- dostosowanie własnych wartości i wiedzy do prawa takiego, jakim ono jest,

- dążenie do zmiany lub modyfikacji norm prawnych,

- „dokonanie schizoidalnego rozszczepienia wartości na własne i reprezentowane przez instytucje"139.

Postawa pierwsza nie może zyskać akceptacji, ponieważ wynika z przyjęcia założenia, że prawo jest wartością samą w sobie, czyli założenia o autonomicznym charakterze norm prawnych ${ }^{140}$. Założenie to zostało przeze mnie odrzucone już na początku niniejszych rozważań ${ }^{141}$. Normy prawne nie kreują bowiem wartości, lecz tworzone są po to, aby określone wartości gwarantować, ochraniać i pomnażać. W literaturze jako uzasadnienie odmówienia prawu autonomicznego charakteru oraz nietraktowania go jako wartości samej w sobie powołuje się zarzuty dotyczące „postaw bezkrytycznego legalizmu, jurydyzacji życia społecznego czy kryzysu zaufania do prawa"142. Uważam więc, że jedynie druga $\mathrm{z}$ wymienionych postaw może być zaakceptowana, ponieważ wiąże wartości z podejmowaniem działań przez jednostki mających na celu poprawę jakości i zwiększenie adekwatności regulacji prawnych. Pozostałe postawy przyczyniają się bowiem do pogłębienia aksjologicznego kryzysu prawa oraz skutkują „demoralizacją" podmiotów przyjmujących takie postawy. Zdaniem

137 Szerzej zob. W. Łączkowski, Demokratyczne prawo wyborcze RP, Warszawa 2000, s. 25.

${ }^{138} \mathrm{Na}$ taką triadę możliwości wskazuje Z. Szonert, op.cit., s. 25.

139 Określeniem tym posługuje się E. Łojek, używając terminologii R.K. Mertona. Zob. E. Łojek, O roli zawodów prawniczych $w$ dzisiejszym społeczeństwie, „Palestra” 1997, nr 3-4, s. 56; R.K. Merton, Rola intelektualisty w instytucjach państwowych, (w:) Teoria socjologiczna i struktura społeczna, Warszawa 1982, s. 278.

${ }^{140}$ Szerzej na temat ujęcia prawa jako wartości samej w sobie zob. M. Borucka-Arctowa, Rola prawa jako czynnika kulturotwórczego, „Zeszyty Naukowe UJ”, „Prace z Nauk Politycznych” 1991, z. 28, s. 70. Por. także W. Gromski, Zagadnienie granic instrumentalizacji prawa, (w:) Z zagadnień teorii i filozofii prawa. Instrumentalizacja prawa, red. A. Kozak, Kolonia Limited, Wrocław 2000, s. 74-95.

141 Również J. Oniszczuk trafnie zauważa, że „uwagi o istnieniu prawa jako elementu kultury i uzależnieniu jego przemian od procesów dokonujących się w kulturze powodują, że pojęcie o pełnej autonomii prawa i traktowane też w taki sposób, a więc już całkowicie specyficznej i odrębnej nauki oraz wiedzy prawników, nie uzyskuje potwierdzenia w nauce". J. Oniszczuk, Kultura i wartości prawne, op.cit., s. 19.

142 W. Gromski, op.cit., s. 93. 
E. Łojek prowadzą one także paradoksalnie - bo pod pozorem legalizmu - do lekceważenia przez prawników wewnętrznej aksjologii prawa i dążenia do swoiście pojmowanej biegłości profesjonalnej, która sprowadza się do naginania prawa, wyszukiwania luk w prawie, znajdowania sposobów obejścia prawa ${ }^{143}$. Odmienne stanowisko prezentuje T. Biernat, który stwierdza, iż „bardziej prawdopodobna wydaje się teza, że »oddalenie« w wyniku przemiany norm od wartości jest w stanie doprowadzić do dezorganizacji systemu aksjonormatywnego, chaosu, który będzie dysfunkcjonalny dla działań społecznych podlegających regulacji, niż ich dowolne "nagięcie” (np. w drodze reinterpretacji) do sfery wartości"144. Problematyka ta znajduje się poza tematem niniejszej dysertacji, dlatego nie będzie szerzej omówiona.

Słuszny wydaje się więc pogląd J. Oniszczuka, iż „wartości ujęte są w kulturze i wyrażają się w pewnych celach ludzi. Cele te nawiązują do przyjmowanych hierarchii wartości. Wobec tych celów kierowane są aspiracje, aby je osiągnąć, zwłaszcza gdy chodzi o cele odpowiadające wartościom wysoko określonym w ich porządku"145. Równocześnie należy zaznaczyć, iż hierarchiczny porządek wartości, czyli określenie, którą z wartości umiejscowimy wyżej na skali preferencyjnej, dokonuje się każdorazowo $\mathrm{w}$ poszczególnych aktach preferowania ${ }^{146}$ dokonywanych przez każdą jednostkę.

Trzy wartości wchodzące w skład idei prawa G. Radbrucha są wartościami powszechnie $\mathrm{w}$ społeczeństwie podzielanymi oraz trwałymi. $\mathrm{Na}$ ich podstawie możemy przeprowadzić linię demarkacyjną między tymi elementami systemu gospodarczego, które mogą być przedmiotem działań prawodawczych, oraz tymi, które należy wyłączyć spod prawnej regulacji. Wartości te umożliwią także wyznaczenie zakresu oraz stopnia szczegółowości dopuszczalnych działań prawodawczych. Jeżeli zaś wartości te staną się - wyłączną i ostateczną - podstawą tworzonych regulacji prawnych gospodarki, to przesądzą o charakterze całego systemu gospodarczego ${ }^{147}$.

Idea prawa G. Radbrucha jest także skutecznym narzędziem w pokonywaniu emotywizmu. Emotywizm prowadzi bowiem do sytuacji, w której mamy do czynienia z szeregiem różnych rozproszonych wartości, których nie da się uzgodnić, ponieważ nie istnieje jakaś jedna przewodnia wartość, np. idea dobra. Natomiast idea prawa wskazuje na konglomerat trzech takich wartości spełniających kryteria „przewodności” i stanowiących podstawę uzgodnienia wszystkich rozproszonych

\footnotetext{
143 E. Łojek, op.cit., s. 56.

144 T. Biernat, op.cit., s. 129.

145 J. Oniszczuk, Kultura i wartości prawne, op.cit., s. 20.

146 Por. M. Scheller, Der Formalismus in der Ethik und die materiale Werthethik (Materialne a priori w etyce, tłum. A. Węgrzecki, „Znak” 1967, nr 12 (162), podaję za: J. Hartman, op.cit., s. 260).

147 Por. nt. wpływu określonych wartości poddanych regulacji normatywnej na charakter porządku społecznego: K. Pałecki, Prawoznawstwo..., op.cit., s. 82 oraz A.R. Radcliffe-Brown, op.cit., s. 140 i n.
} 
wartości, które de facto są treściowo i logicznie możliwe do wyprowadzenie właśnie z triady Radbruchowskiej. Ponadto te trzy wartości w ramach idei prawa „wzajemnie się warunkują, uzupełniają i sobie przeciwstawiają. Wzięta od Arystotelesa formalna Gerechtigkeit (sprawiedliwość w węższym znaczeniu) [...] wypełniona zostaje treścią przez Zweckmäßigkeit [...] i zabezpieczona przez Rechtssicherheit (pewność, stałość prawa, bezpieczeństwo prawne)"148.

Idea prawa Gustawa Radbrucha jest koncepcją, którą we współczesnej filozofii prawa podaje się jako przykład koncepcji odwołującej się do ideału w prawie ${ }^{149}$, bywa także utożsamiana czy też określana mianem „,ideału prawa” ${ }^{150}$, co jest twierdzeniem w pełni zasadnym. Co więcej, takie utożsamienie idei prawa z ideałem czyni ją bardzo użyteczną na gruncie nie tylko filozofii prawa, ale wbrew powszechnemu mniemaniu także w socjologii, w tym socjologii prawa. Potwierdzeniem tej tezy zdają się być słowa samego E. Durkheima, który stwierdzał, iż „podstawowe zjawiska społeczne, religia, moralność, prawo, ekonomia, są nie czym innym, jak systemami wartości, a więc ideałów. Socjologia porusza się więc w sferze ideału: nie dochodzi do niej stopniowo pod koniec swych studiów, lecz bierze ją za punkt wyjścia. Ideał stanowi właściwą jej dziedzinę badań”"151.

Należy zatem uznać za trafny pogląd formułowany przez J. Zajadło, iż „koncepcja trójelementowej idei prawa - bezpieczeństwo, celowość, sprawiedliwość - wyczerpuje znamiona uniwersalnego kryterium oceny jakości prawa, ponieważ pozwala na racjonalną identyfikację, kontrolę i rozwiązywanie konfliktów pomiędzy różnymi wartościami prawa z zachowaniem homeostazy systemu prawa jako całości” ${ }^{152}$. Równie cenną i doniosłą jej zaletą jest możliwość równoczesnego, systematycznego, a wynikającego z dynamiki życia społecznego redefiniowania poszczególnych wartości idei w taki sposób, aby ich treść była w jak największym zakresie i stopniu adekwatna względem aktualnej rzeczywistości społeczno-gospodarczej ${ }^{153}$.

148 D. Bogacz, Formuła i filozofia prawa Gustawa Radbrucha... W związku z książką: J. Zajadało, Formuła Radbrucha. Filozofia prawa na granicy pozytywizmu prawniczego i prawa natury, Arche, Gdańsk 2001, „RPEiS” rok LXIV, 2002, z. 3, s. 30-31.

149 J. Zajadło, Idea (ideał) prawa, op.cit., s. 121-122.

150 Ibidem.

151 J. Szacki, Historia myśli socjologicznej, PWN, Warszawa 2002, s. 388.

152 J. Zajadło, Dziedzictwo przeszłości..., op.cit., s. 81.

153 Por. ibidem, s. 82. 


\section{Wnioski}

Na podstawie zaprezentowanych argumentów formułuję twierdzenie, że tylko taki system prawny, którego regulacje tworzone byłby na podstawie trójelementowej idei prawa Gustawa Radbrucha (która stanowiłaby równocześnie granicę wkraczania $\mathrm{z}$ ingerencją prawną $\mathrm{w}$ określany fragment stosunków społecznych na zasadzie przyjęcia, że triada wartości składających się na ideę prawa stanowi desygnat wspólnego trzonu aksjologicznego twórców i adresatów prawa, wyznaczając równocześnie minimalny zakres, jaki prawodawca musi uwzględniać w każdej tworzonej regulacji i jednocześnie maksymalny zakres tego, co może podlegać uregulowaniu prawem), byłby w sferze postulatywnej systemem idealnym. Wykorzystanie tej idei przez prawodawcę warunkuje powstanie optymalnego, adekwatnego i efektywnego prawa - czyli takiego, które najpełniej uwzględnia społeczne postulaty względem prawa, jest więc prawem społecznie pożądanym, a co za tym idzie dobrze uspołecznionym. Z kolei treść tych wartości przesądza o treści zasad ustrojowych danego systemu gospodarczego. Tak więc wartości idei prawa spełniające rolę jednoczesnego wyznacznika:

- zarówno minimalnej, jak i maksymalnej granicy prawnej regulacji systemu gospodarczego,

- podstawy aksjologicznej tworzonej regulacji,

- wyznacznika treści regulacji gospodarczej,

- wyznacznika treści i zakresu zasad ustrojowych systemu gospodarczego,

- narzędzia oceny jakości tworzonego prawa,

mogą stanowić idealne narzędzie wyznaczania i konstytuowania granic regulacji prawnych gospodarki. Regulacjom prawnym kreowanym zgodnie z ideą prawa przysługiwał będzie przymiot „prawego prawa” ${ }^{54}$, czyli prawa równocześnie sprawiedliwego, bezpiecznego i celowego, a zatem racjonalnego (opartego na najlepszej wiedzy).

\footnotetext{
154 Autorstwo wyrażenia „prawe prawo” przypisywane jest F. Zollowi, który posługiwał się nim w swoich dziełach. Por. F. Zoll, Prawo cywilne w zarysie. Część ogólna, t. I, Kraków 1946, s. 53.
} 


\section{Axiological problems as conditions in economic jurisprudence and the limits of economic law}

The dissertation substantiates the possibility of applying the idea of law as a tool for defining the limits of legal interference in an economic system. Adopting the concept of law based on the Economical Analysis of Law it advocates the belief that the implementation of the idea of law consisting of three values - advisability, justice and legal safety - is the most optimal and effective instrument in determining the limits of legal regulations with regard to a liberal market economy. One can conclude then, that the idea of law can very well be described as a general cultural axiological system, especially with regard to the economic and legal culture. It is a system of values that determines the processes of internalization and institutionalization of norms and above all legal and moral ones.

The law is a factor that determines and organizes the social life and it determines for the same reason the art and limits of economic activities. It cannot therefore be enacted in isolation from economic and axiological questions. As Gustav Radbruch observes, the law, as well positive as the natural law is a cultural phenomenon and can be looked into only in connection with values and always with reference to them. The positive law must embody and implement the idea of law. And although it is indisputable that no ideal legal or economic system can be completely fulfilled, the striving toward those ideals is an obligation for any society. Resigning and giving up the ideal does not simply mean the preservation of the status quo, but it results in regression and in repeating of former dysfunctions and/or other negative solutions.

\section{Les problèmes axiologiques qui conditionnent la législation économique et sa limitation. Questions philosophiques et juridiques}

Cet article justifie la possibilité d'appliquer l'idée de droit comme un outil pour définir les limites de l'interférence juridique dans un système économique. Adopter le concept de droit fondé sur l'analyse économique du droit préconise la conviction que la mise en ouvre de l'idée de droit constituée de trois valeurs -opportunité, justice, sécurité juridique - est l'instrument le plus optimal et efficace pour déterminer les limites de la réglementation juridique en ce qui concerne léconomie de marché. On peut donc conclure que l'idée de droit peut très bien être décrite 
comme un système axiologique et culturel général, en particulier en ce qui concerne la culture économique et juridique. Il s'agit d'un système de valeurs qui détermine les processus de l'internalisation et l'institutionnalisation des normes, avant tout celles juridiques et morales.

Le droit est un facteur qui détermine et organise la vie sociale et détermine pour la même raison l'art et les limites des activités économiques. Par conséquent, il ne peut être adopté indépendamment des questions économiques et axiologiques. Comme Gustav Radbruch constate, le droit - naturel et positif - est un phénomène culturel et il peut être examiné que dans le cadre de valeurs et toujours en référence à elles. Le droit positif doit incarner et mettre en œuvre l'idée de droit. Même s'il est incontestable quaucun système juridique ou économique idéal ne peut être complètement rempli, l'effort vers ces idéaux est une obligation pour toute société. Renoncer à l'idéal ne signifie pas simplement la préservation du statu quo, mais il en résulte une régression et une répétition des dysfonctionnements anciens et / ou d'autres solutions négatives. 